Portland State University

PDXScholar

1976

Residential treatment of emotionally disturbed adolescents

Rosemary Brown Sutherland

Portland State University

Follow this and additional works at: https://pdxscholar.library.pdx.edu/open_access_etds

Part of the Child Psychology Commons, and the Social Work Commons Let us know how access to this document benefits you.

Recommended Citation

Sutherland, Rosemary Brown, "Residential treatment of emotionally disturbed adolescents" (1976). Dissertations and Theses. Paper 1973.

https://doi.org/10.15760/etd.1972

This Thesis is brought to you for free and open access. It has been accepted for inclusion in Dissertations and Theses by an authorized administrator of PDXScholar. Please contact us if we can make this document more accessible: pdxscholar@pdx.edu. 


\title{
RESIDENTIAL TREATMENT OF EMOTIONALLY \\ DISTURBED ADOLESCENTS
}

$\because$

by

ROSEMARY BROWN SUTHERLAND

\begin{abstract}
A practicum submitted in partial fulfillment of the requirements for the degree of
\end{abstract}

MASTER OF SOCIAL WORK

Portland State University

1976 
TO THE OFFICE OF GRADUATE STUDIES AND RESEARCH:

Approved by:

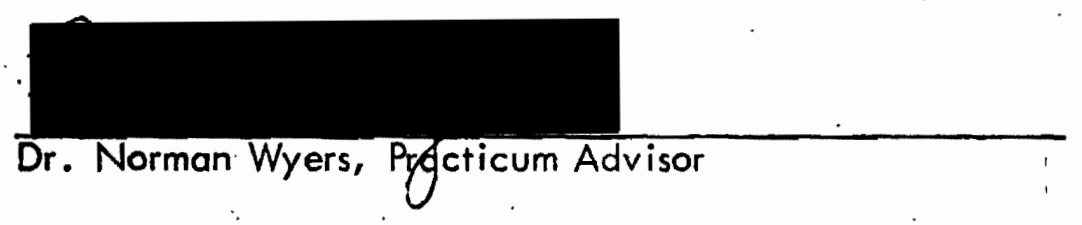




\section{ACKNOWLED GEMENTS}

The author would like to acknowledge the generous contribution of

directors of several adolescent treatment programs and of officials of the Mental. Health Division, Children's Services Division and the Department of Human Resources.

Special thanks and appreciation are due to my advisor, Dr. Wyers, and to the many friends and colleagues who offered assistance and encouragement towards the completion of this study. 


\section{TABLE OF CONTENTS}

PAGE

ACKNOWLEDGMENTS $\ldots \ldots \ldots \ldots \ldots \ldots \ldots \ldots \ldots \ldots$ ii

\section{CHAPTER}

I INTRODUCTION ................... I

Purpose $\ldots \ldots \ldots \ldots \ldots \ldots \ldots \ldots \ldots \ldots \ldots$

Method $\ldots \ldots \ldots \ldots \ldots \ldots \ldots \ldots \ldots$ I

II THE REVIEW OF THE LITERATURE $\ldots \ldots \ldots \ldots \ldots \ldots$

History of Residential Treatment $\ldots \ldots \ldots \ldots \ldots \ldots \quad 4$

Characteristics of Residential Treatment . . . . . . $\quad 5$

Population .................. 9

Philosophy $\ldots \ldots \ldots \ldots \ldots \ldots \ldots \ldots \ldots \ldots$

Method $\ldots \ldots \ldots \ldots \ldots \ldots \ldots \ldots \ldots$

The Family ................. 27

Discharge/Placement/Aftercare $\ldots \ldots \ldots \ldots \ldots . . .28$

Research and Evaluation $\ldots \ldots \ldots \ldots \ldots \ldots$

Innovations and Alternatives $\ldots \ldots \ldots \ldots \ldots \ldots .33$

Summary $\ldots \ldots \ldots \ldots \ldots \ldots \ldots \ldots \ldots \ldots \ldots \ldots$ 
CHAPTER

PAGE

III NEED FOR SERVICE .................. . 40

The View of the Mental Health Center ......... 40

The Community View .............. 43

Summary ........................ 47

IV PROGRAM OPTIONS .................. 48

Secure Treatment Facility . . . . . . . . . . . . . 49

Benefits

Shortcomings

Discussion

Non-Secure Residential Treatment (Group Home) ....

Benefits

Shortcomings

Discussion

Day Treatment Program ...............

Benefits

Shortcomings

Discussion

A Fourth Possibility ................. 57

Day Treatment $/$ Group Home ............. 58

Benefits

Shortcomings

Discussion

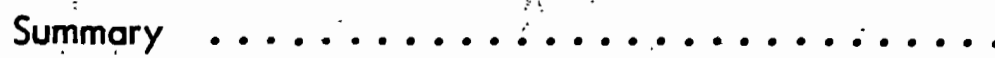

V SUMMARY AND CONCLUSIONS ............. 61 
PAGE

. SOURCES CONSULTED $\ldots \ldots \ldots \ldots \ldots \ldots \ldots \ldots \ldots \ldots \ldots \ldots$. 64 APPENDIXES

A PURCHASE. OF CARE PLACEMENTS THROUGH CHILDREN'S SERVICES DIVISION ........... 72

B SUBCONTRACTING FOR TITLE XIX PAYMENTS THROUGH THE MENTAL HEALTH DIVISION $\ldots \ldots \ldots 8$

C PROPOSED DAY TREATMENT PROGRAM FOR CLACKAMAS COUNTY ............... 101

D A GROUP HOME/HOSPITAL TREATMENT MODEL FOR DISTURBED ADOLESCENTS 


\section{CHAPT ER I}

\section{INTRODUCTION}

\section{PURPOSE}

This study was requested by Dr. Ira B. Korman, Administrator; Woodland Park Mental Health Center. Woodland Park Mental Health Center currently provides a program of short-term evaluation and crisis care for adolescents. The staff there find it is difficult to locate suitable out-of-home placements for certain of their adolescent patients concluding hospitalization. Their concern for this group of hard-to-place patients has led to this inquiry, the purposes of which are to (1) assess need, (2) design a residential program, and (3) consider the feasibility of its implementation.

\section{METHOD}

In order to fulfill the goal of a well-researched design for adolescent treatment services, one attuned to current environmental factors as well as the best of documented clinical knowledge about the treatment of disturbed adolescents, a multifaceted approach is required. A thorough review of the literature of the several disciplines historically involved with adolescent treatment is necessary. Of special concern is the effectiveness of various models of treatment. In 
addition, other factors which may affect the outcome of residential treatment will be considered. Attention will be directed toward factors such as staffing patterns, staff role designations, administrative patterns, the location of policymaking, length of stay, the degree of interaction with the community, methods of structuring family involvement, and the use of a school program.

In order to design services to address those needs of troubled adolescents which are currently unmet in Northwest Oregon, it will be necessary to confer with the directors of existing programs to determine which services those programs offer and learn of any planned expansion. Additional contacts will be made with those agencies which are responsible for determining service gaps on a local, regional and state basis. These agencies (primarily the Mental Health Division, the Children's Services Division, and the Department of Human Resources) are in a position to monitor the changing need for service and thus occupy a vantage point from which to advise on the design of service components.

As these same agencies have the responsibility to recommend to policymaking bodies the most efficient use of scarce social service resources, the priorities for service identified by them may indicate the feasibility of implementing treatment programs which rely on any social service resources. Because of the high cost of residential treatment, it is likely that the unavailability of any social service money would severely limit the population which could be served.

The program must be designed in light of the accumulated knowledge of the professional literature, the informed assessment of service need, and the 
obvious effect of the distribution of resources. Additionally, at the request of Dr. Korman, a key element in the design of the treatment program will be the collective clinical knowledge of those staff members at Woodland Park Mental Health Center who are currently working with adolescents. 


\section{CHAPTER II}

\section{THE REVIEW OF THE LITERATURE}

\section{HISTORY OF RESIDENTIAL TREATMENT}

The majority of today's residential treatment facilities emerged from institutions whose original goals were the shelter, care, and training of dependent children. Maluccio and Marlow state, "Residential centers for children are a twentieth century phenomenon, stemming from Aichhorn's application of psychoanalytic concepts to work with children and youth." (1972, p. 230) Although Aichhorn's primary work, Wayward Youth, was not published until 1934, it was in 1920 that he first called attention to the planned use of the "milieu" as a therapeutic tool. Aichhorn described the milieu in terms of a psychoanalytic understanding of the individual child's needs. Other pioneers in exploring the effect of the milieu included Bruno Bettelheim, who established the Orthogenic School in Chicago, and Fritz Redl and (subsequently) Dovid Wineman of Pioneer House in Detroit.

At the same time that child caring institutions were redefining their mis: sion and new forms of care were evolving, psychiatric hospitals were debating the need for hospitalization for adolescents and children. A continuing debate was begun on the benefit of separating adolescent from adult patients in living unit and/or program. In 1937, Curran established the first strictly adolescent ward at 
New York City's Bellevue Hospital. (Nichtern 1968, p. 115) The movement toward all-adolescent wards in treatment hospitals was slow enough that seventeen years later when Hillside Hospital established its girls' pavillion in 1954, it was still considered "one of the first." (Nichtern 1968, p. 131)

In Oregon, as late as 1965, none of the state hospitals had a program for children or adolescents. This was true even though state hospitals in Oregon had admitted seventy-two children under fifteen years of age in the fiscal year 1962-1963. (Taylor 1965, p. 79)

\section{CHARACTERISTICS OF RESIDENTIAL TREATMENT}

There appears to be no one clear definition of what a residential treatment center is or does although "residential treatment" is popular among child caring centers as a self-description. Maluccio and Marlow conclude that it could generally be defined as "a total therapeutic program for children whose emotional problems preclude treatment in the community on an outpotient basis." (1972, p. 232) They found that a residential treatment center generally included the following:

Structure or planned and controlled living.

Group living and individuation.

Identification through opportunities for significant relationships.

Child-staff interaction.

Integration and joint planning and evaluation of the child's treatment plan by all staff. (Maluccio \& Marlow 1972, p. 232) 
To that list Mayer would add the following characteristics to define residential treatment as he envisions it:

Treatment based on diagnosis.

Education included among the goals.

Interaction and coordination between the environment and treatment therapy. Effective utilization of the therapeutic potential of all staff.

Provision for staff training.

Work with parents (noted as essential). (Mayer 1955, p. 667)

Adler simplifies to four the components of residential treatment. He lists these as diagnosis, a therapeutic environment, casework and psychotherapeutic services, and synthesis through ongoing communication of the various disciplines. The synthesis would include joint treatment planning and the evaluation and implementation of treatment objectives. (Adler 1968, p. 519)

In large part, residential treatment is characterized by a diversity of programs and services which have developed out of differences in history, population, purpose, and theoretical orientation. (Child Welfare League of America 1964, p. 10) One major difference, alluded to earlier in this review, has been the evolution from two separate directions, psychiatry and child care, of a treatment format called residential treatment. Psychiatric hospital care for adolescents and the program of child caring institutions have been influenced by each other and by other forces. One important factor has been sociological studies into the 
residential treatment center as an institution and the effect of staff and patient interactions.

Although the boundaries between residential treatment of adolescents in psychiatric hospitals and in child care institutions are becoming less and less clear, attempts have been made to distinguish between them as providing "closed" as opposed to "open" settings. These are commonly differentiated in terms of the program provided and the criteria for admission.

According to Glickman, the "closed" setting provides a "hospital type" of treatment for children such as the schizophrenic, while the "open" setting designed for less disturbed children offers a diverse program and a "corrective emotional experience." (Taylor and Alpert 1973, p. 80-101) This statement, while making one useful suggestion for admission criteria, seems to neglect the substantial portion of adolescents who come to the attention of treatment facilities through delinquent activities and who may elope from the "diverse program" of the open setting before there is time for them to be affected by the "corrective emotional experience." There appears to be a group who needs more control than can be provided in an open setting and yet may need diverse programming and corrective experiences. Most programs seem to have a continuum of privileges, that is, various degrees of openness, to accommodate changing individual needs.

Taylor, in his 1965 report to Oregon's Mental Health Planning Board, suggested that hospitals are able to take children not suited for non-hospital 
programs such as those with organic problems, the severely autistic, fire setters, and, more generally, those needing a locked facility. (1965)

Kadushin noted the following major trends in children's institutions in recent years:

1. Expanded use of the institution as a specialized resource rather than as an undifferentiated facility for all children needing substitute care.

2. Feiwer referrals of children but of children with more severe problems:

3. The movement from custody to treatment.

4. Increased professionalization and upgrading of staff.

5. Efforts to "de-institutionalize" the institution.

6. Efforts to involve parents more actively in the program. (Kadushin 1967, p. 554)

Despite many changes in the characteristics of residential institutions, they continue to be a major means of coping with certain societal problems, most particularly to care for those labeled mentally ill, retarded or delinquent.' (Holland 1973, p. 241)

One predictable characteristic of residential treatment is that it is expensive. A 1964 study by the Child Welfare League of America found that costs per child per year ranged from $\$ 4,403$ to $\$ 17,947$ for established programs. (Hylton 1964, p. 174) The average cost per child per year at ten "high quality programs" was $\$ 9,684$. (Hylton 1964, p. 166) In 1973 the average yearly cost of care was found to have increased to approximately $\$ 13,000$ per child. (Taylor \& Alpert 1973, p. 2) In a major study attempting to discover why the cost of 
residential treatment is so high, it was concluded that the number of professional staff in relation to the number of children in care is one of the major factors affecting the cost of residential treatment. Additionally, the cost of medically directed programs is significantly higher than those of non-medically-directed programs. (Hylton 1964, p. 187). On the other hand, the proportion of disoriented or extremely aggressive children in ten of the centers was tested in relation to cost with no significant correlation found. (Hylton 1964, p. 187)

\section{POPULATION}

One recurring issue is the question, "For whom is residential treatment appropriate?" Maluccio and Marlow find that the question is compounded by the lack of a clear definition of "emotional disturbance." (1972, p. 237) Kanner states that "[the term] emotional disturbance has been used widely, sometimes as a generality with no terminological boundaries whatever and sometimes with reference to certain psychotic or near-psychotic conditions." (1962, p. 101)

Residential treatment, then, is sometimes considered to be the appropriate treatment for emotional disturbance, but neither "residential treatment" nor "emotional disturbance" has been conclusively defined. Despite this problem, clinicians of many professions daily need to deal with the question of referral to residential treatment. As Taylor concludes,

When serious emotional disturbance occurs in adolescence, it cannot be ignored. If he [the adolescent] attempts to solve his problems by aggressive behavior, his size and strength make it impossible for parents or teachers to 
control his behavior. If he withdraws, attempts suicide, or acts out sexually, his family and community have to respond. (Taylor 1965, p. 39)

Presenting problems for youth admitted for residential care are likely to be self-injury, running away, aggressive acting-out, delinquency, and unacceptable sexual expression. (Levy 1971) Presenting problems of younger children may also include passive-aggressive behavior and hyperactivity. (Maluccio 1974, p. 229)

Linsey introduces another view of the population of residential treatment centers. He sees the mental hospital as a means of social control whose patients are there because the community has determined their behavior to be unmanageable (i.e., delinquent) or inappropriate (i.e., depressed, suicidal or annoyingly bizarre). (Lindsey 1974) Dettelback cautions that one should decide to admit a child to residential treatment only when his problems are so severe "qualitatively and quantitatively so as to preclude treatment within the family. "(1955, p. 674) In Oregon, the Mental Health Division, in a study which eventually led to the establishment of several Child Study Treatment Centers throughout the state, suggested that the hospitalization of adolescents at the state hospitals was, in many cases, an arbitrary choice, caused by deviant behavior which the community feels unable to handle and "which could be treated through some active community intervention." (Oregon Mental Health Division 1969, p. 13) Even distant and arbitrary conditions, such as the overcrowding of juvenile corrections facilities, can influence placement in a state hospital. (Lindsey 1974, p. 140). 
There has long been considerable concern for defining criteria for referral and placement but often these criteria are stated in vague, general terms. One common theme seems to be the need for a differential diagnosis as a basis for planning. *

General issues in admissions criteria are (I) the dynamics of family relationships, (2) the child's development history, (3) the nature and extent of symptoms, (4) the prognosis or change in the child and his parents, and (5) the availability of psychiatric outpatient or other rehabilitation facilities in the community. (Maluccio \& Marlow 1972, p. 238; Levy 1971, p. 20) Lerner suggests other issues, such as the length of stay required, the age of the child and the amount of symptom tolerance in the family, school and community. (1952) D'Amato sees criteria for admission to full residential treatment in terms of the child's needs for separation, for special education, and for psychiatric treatment. He concludes that any one or two of these needs could be provided for in group homes, day centers or within the child's own family and that the child should be referred for treatment only if all three needs are present. (D'Amato 1969, p. 26) Despite concurrence of many authors on the issues involved in the decision to refer for residential treatment, Maluccio and Marlow insist that "the decision to place a child in residential treatment is presently a highly individualized matter based on a complex set of idiosyncratic factors defying categorization." (1972, p. 239)

*This is the idea behind Oregon's established Child Study Treatment Centers and the Adolescent Study Treatment 'Centers to be proposed to the 1977 Legislature. 
One side issue in residential treatment within psychiatric hospitals is the question of whether or not adolescents should be mixed with adults in a general treatment program, should share living units with adults but participate in an adolescent treatment program, or should be separate from adults both in living quarters and program. Gossett et al. cite a study by Beavers and Blumberg which strongly suggests that those hospitals offering a specialized adolescent treatment program had better long term results, especially for schizophrenic and character disordered patients. They conclude that this observation was supported in later studies. (1973, p. 607)

Gralnick, on the other hand, found that there were sufficient referrals to transform his hospital to an altadolescent hospital, but held the adolescent population to 40 or 50 percent, seeing the all-adolescent hospital as an artificial climate which leads to the unmanageable behavior of the gang. (Nichtern 1968) Policy at the University of Texas Medical School Hospital reflects the conviction that the presence of adult patients among adolescents reduces tension and allows for mutual benefit. They limit the adolescent population on any ward to 70 percent of the total. (Beavers 1968, p. 10)

The importance of this issue became apparent when one considers that adolescents and young adults are being admitted to mental hospitals at rates higher than all other age groups. (Flomenhaft 1974, p. 66) In 1971 adolescents comprised 25 to 30 percent of the patient population in psychiatric hospitals. (Levy 197I, p. 18) In 1969 the N.I.M.H. predicted that the overall residential 
population will decrease by 18 percent, but that the percent of those patients who are young will increase by 90 percent. (Oregon Mental Health Division 1969, p. 10) Other evidence that an increase in young psychiatric patients is likely is found in the government prediction that by 1985 one-half of the United States population will be less than twenty-one years old. (Nichtern 1968, p. vi)

\section{PHILOSOPHY}

A residential treatment setting must adhere to a coherent philosophy regarding the bringing up of children in general and a philosophy of treatment in particular. (Levy 1971, p. 20; Beavers 1968, p. 11) Beavers ventures the opinion that

No special theoretical model of psychopathology seems to be needed to run a successful adolescent unit. However, it is essential that whatever treatment philosophy is used, we make its main outlines simple and clear enough to be transmitted [to everyone]. (1968, p. 11)

The treatment philosophy is necessary for continuity and predictability in the living unit, and to enable all staff to be agents of the therapeutic experience (or at least not to detract from therapy done by others). The philosophy usually develops out of an understanding of the cause and/or cure of the pathology. Those locating the "illness" in the resident are likely to develop a different philosophy and to behave differently than those emphasizing a sick environment. (Stannard 1973) 
Recurring issues in treatment philosophies are:

1. The cause of the disturbance (usually seen as a lack of something).

2. The goal or goals of treatment (usually an attempt to supply that which is/was lacking and how this might be done).

3. The desirable degree of structure and control--and acceptable methods for achieving and maintaining these.

4. The roles; responsibilities and decision-making power of staff members (and patients), particularly a concern with who is the "primary therapist" or a question of how members of "the team" will function together.

5. The role in treatment of the patient's family.

Maluccio and Marlow state that the prevalent form of philosophy of residential treatment has been that of "individual centered treatment." (1972, p. 235) Before the 1960s, writers typically underscored the psychological aspects of treatment. Major therapeutic objectives were the resolution of intrapsychic conflicts, the development of insight, and the reorganization of the child's personality. (Maluccio \& Marlow 1972, p. 235)

The views of Donald Rinsley illustrate some of the ways this theory may translate into practice. Donald Rinsley states that the great majority of adolescents admitted to psychiatric hospitals are psychotic or borderline psychotic. They are described in ego psychological terminology as symbiotic or pre-symbiotic and the goal is defined as "reconstructive treatment" leading to lasting healthy personality change. Emphasis is not on the milieu but on the therapeutic relationship 
with a psychiatrist. A three-phase course of treatment is expected to last approximately three years. Staff roles are to be clearly delineated with the psychiatrist making treatment decisions after seeking staff input. Families are to be dealt with through casework. (Adilman 1973, p. 547)

The importance of the "environment" of residential treatment has been recognized since Aichhorn delineated the idea of the therapeutic milieu in Wayward Youth. (Trieshman 1969) Bettelheim and Sylvester developed the concept in 1948. (Maluccio \& Marlow 1972, p. 234) A third primary figure is Redl. Aichhorn, Bettelheim and Redl all had an ego-psychiatric orientation and were concerned. with how the living situation could be planned around the ego's functioning for the purpose of supporting and nourishing its functioning and development. (Trieshman 1969)

The views of Bettelheim give a clear example of how the emphasis on the milieu blended with the theoretical stance which emphasized the psycho-dynamic aspects of tr eatment. Bettelheim states that the cause of emotional disturbance in children is emotional deprivation, particularly deprivation of a constant relationship from which to form a framework for interpersonal relationships. (Adilman 1973, p. 558) For Bettelheim, the goal of treatment is to provide this experience through encouraging interpersonal relationships, peer group support and influence, a formal school program, and adult protection. Rules are minimized to enable "autonomous self-regulation." (Adilman 1973, p. 558) The main responsibility for treatment is given to the residential staff because in order to deal 
therapeutically with all types of behavior, they must have total responsibility. He recommends the use of young people because of their "enthusiasm, zeal and contagious belief in human potentialities." (Adilman 1973; p. 558) Bettelheim maintains that parents often sabotage their child's therapy and that one value of residential treatment is that it lets the child live outside the reach of his parents. (Adilman 1973, p. 558)

Other examples of theories emphasizing intrapsychic conflicts and personality reorganization are available. Many of these are summarized succinctly in Adelman's work. (1973, p. 554-565) Basic agreement on cause or cure does not necessarily lead to similar approaches to control, staff role and therapeutic responsibility. This can be seen in a comparison of the philosophies of Bettelheim and Rinsley above. One common understanding is that therapists will focus on emotional turmoil in therapy hours while resident staff deal with behavior throughout the day. The major theorists discussed so far have been psychiatrists who were dealing primarily with hospital situations. A similar stance, however, is often found within child caring institutions, in which the caseworker is considered the "primary therapist" or "primary relationship, "and the child care staff or house parents are expected to deal with behavior.

Some have attacked the classic psychiatric diagnosis as too often selffulfilling. Expectations are communicated and the resultant behavior is described as reflecting an "ego deficit," rather than as behavior appropriate to the immediate social situation. (Westmaas 1971) Staff admitting an adolescent in a state of 
"ego disorganization" are seen as failing to account. for the traumatizing effect of referral and admission to a facility for the emotionally disturbed. (Lindsey 1974, p. 143)

Abend et al. refute the need for long hospitalization which is assumed by many of those who seek personality reorganization. They cite the emphasis of Community Mental Health on minimizing the degree and duration of separation from the family. They also propose that significant interaction can take place with the child care personnel. (Abend et al. 1968, p. 949)

Others have also protested prolonged institutional care. Flomenhaft indicated that institutional care, especially at a distance from home, encourages. chronicity. During hospitalization, the family often closes ranks against the patient and reorganizes by having other family members take over the patient's normal functions. He concludes that the longer the patient is away from home the more difficult it is to reintegrate into the family and community. (Flomenhaft 1974, p. 57)

In the early 1960s the residential treatment center was studied by social scientists who then discussed the importance of the social system which surrounds patients and staff in a treatment facility. (Maluccio \& Marlow 1972, p. 233) Early examples are Stanton and Schwartz, The Mental Hospital, 1954; Goffman, Asylums, 1961; and Cummings and Cummings, Ego and Milieu, 1963. More recent commentary includes the works of Thomas Szasz and D. Laing. Significant. work was done by Polsky et al. in 1962. They used sociological methods to analyze 
the impact of various subsystems and subcultures of staff and residents. (Maluccio \& Marlow 1972, p. 232) Levy, writing from the Children's Hospital of the Menninger Clinic, states that aside from separation from a destructive environment, what is therapeutic about the progress is "a chance to point out (confront) again and again, as it happens, the personality tendencies repeatedly expressed which are appropriate to the actual current circumstances." Patients can be made aware of their misperceptions. (Levy 1971, p. 21)

In The Other 23 Hours the authors define the goal of the milieu as "behavioral change" in the child, but do not limit the behavior to that which is observable. This change is to come through teaching, and five "teaching formats" are outlined. These include rules, routines, programming and activities, managing surface behavior, and conversations which may be general, psychotherapeutic or life-space interviews. (Trieshman et al. 1969)

Some, emphasizing the sociologically defined importance of the peer group, have tried to center treatment in the group. In Lewis's "Protreatment Group Process," the group is seen as responsible for individual behavior and when an individual acts out, the entire group is restricted until they explore their involvement in the act and find constructive alternatives. (Adilman 1973) Typically in such programs, the group determines privileges.for the individual as well.

Maier has categorized treatment philosophies as:

1. Individually-centered treatment in which the one-to-one therapeutic relationship is the mainstay of the program. 
2. Group-centered treatment in which treatment revolves around living, work or therapy groups.

3. Integrative treatment in which the child-care worker is the pivotal agent in a service stressing utilization of the total institution. (Maier 1965, p. 662)

Maluccio and Marlow conclude that the newer literature reveals a reconceptualization of treatment which approaches Maier's third alternative of "integrative treatment." (1972, p. 235)

There is also a philosophy of residential treatment which maintains that residential treatment should not exist. This theory will be explored subsequently in the section on alternatives to residential treatment.

\section{METHOD}

Probably the primary methodological issue in residential treatment is how to define and structure roles, responsibilities, and decision making of the staff within the "treatment team."

The Menninger Clinic examined the functioning of their professional interdisciplinary team in doing typical outpatient diagnostic evaluations. They found that they had problems of role differentiation, leadership, and communication, and problems in relationships which they labeled "transference" and "countertransference." The problems of an inpatient staff, particularly when that staff is considered a "team," are greater. Levy states, "Integrating the efforts of many 
people, psychiatric as well as paramedical, into a meaningful whole is no mean administrative task." (Levy 1971, p. 20) Browne elaborates further:

The executive must lead his agency towards a solution of its confusion about roles and must help determine which are the most appropriate and effective ways of differentiating, defining and organizing roles in the institution; what alterations in conventional roles must be brought about; how the prestige attached to various roles can best be distributed; what value systems are associated with various roles and how role conflict develops: how various roles can complement each other and be integrated to provide the most effective therapeutic contact. (Browne 1963, p. 81)

Although it is not within the scope of this review to develop a thesis on the cause of intrastaff tension within treatment programs, it is important to explore this issue a bit further, including at this point a discussion of two key articles from sociology and administrative science.

An article by sociologists Fry and Miller explores the effects of using interdisciplinary teams of helping or healing professionals practicing as members of small work groups. They discovered a high degree of job tension. They cite a 1970 study by Horowitz which indicates that team effectiveness and authority patterns arise as a result of concensus which itself derives from bargaining. They found that professionals are not.taught how to bargain about their roles and, thus, are ill prepared to work on interdisciplinary teams. (Fry \& Miller 1974, p. 417) They also found that the individual's influence on the team is determined by the ability to control organizational resources, and therefore, in different settings the members of different professions will dominate. (Fry \& Miller 1974)

Not only are professionals ill prepared to work together as a team (professional identity and the assigned control of resources working against this goal), 
but it is also difficult to combine professionals and bureaucracies. "From the perspective of formal organizational theory, a major contradiction has been noted in the combination of professionals and organizations structured along bureaucratic lines." (Fry \& Miller 1974, p. 418) Theorists indicate that the traditional discussions of authority and hierarchical relationships in organizations are irrelevant to the professional-organizational question. (Fry \& Miller 1974, p. 418) In discussing the relationship between the treatment team and the larger organization, Horowitz sees that decision making and policy development are functions which are fundamental to the operation of the interdisciplinary team. The role of management is merely one of evaluating team performance and possibly influencing policy. The imposition of policy guidelines from outside the team is seen to impair the performance of the team and its morale. To function effectively, interdisciplinary teams must be given autonomy by the larger organization. (Fry \& Miller 1974, p. 418)

The crux of the findings is this:

Organizations which incorporate a quasibureaucratic administrative structure and also allow autonomy to accrue to professionals with in the team structure are generating several potential sources of organizational strain. (Fry \& Miller 1974, p. 430)

Of course, that is precisely the situation of many in-patient treatment focilities, and the problems between professional disciplines, between professionals and paraprofessionals, and between teams and the bureaucracy can be easily recognized in residential treatment settings. 
A 1973 article by Holland discussed the concept of "unitization" which - he describes as one proposal to improve institutional care, to decentralize decision making to lower levels in the organization closer to the clientele and those who are in direct contact with them. The goal is to increase individualization of client services. He concludes that organizational decentralization influences treatment away from an institution orientation and toward a greater individual orientation, and he recommends that decision making be further decentralized and that the role of direct care staff be emphasized in the planning of treatment plans. (Holland 1973, p. 248)

The inclusion of direct care staff in decision making is becoming more and more common. Maluccio and Marlow, citing the 1967 study Child Welfare Services by Kadushin and a similar study by Pappenfort and Kirkpatrick summarize,

Although traditional treatment modalities prevail in most settings, they are increasingly being questioned . . . the trend is away from the medical model of one-to-one therapy, and the triumvirate of psychiatrist, psychologist and social worker is yielding to a team approach encompassing the total staff. (Maluccio \& Marlow 1972, p. 235)

The inclusion of direct care staff (or "line" staff)in treatment teams has been to some extent influenced by sociological studies which demonstrated their substantial influence on treatment. One study by Polsky and Claster summarized the role of the child care worker in residential cottages as "pivotal." (Maluccio \& Marlow 1972, p. 232)

Studies by Caudill and by Goffman demonstrated the substantial impact of nurses and orderlies in psychiatric hospitals. (Stannard 1973) This influence has' 
become greater with the increase of educated and energetic young people into - paraprofessional roles. (Stannard 1973) Although professionals tend to minimize the influence of the line staff, the line staff commonly do not. Nurses and orderlies in Stannard's study felt they were more influential than the doctors in bringing about the patient's recovery. (1973, p. 145)

Works by Konopka and Schulze stressed the importance of the direct care done by group workers in children's institutions. (Maluccio \& Marlow 1972, p. 234) More recently there are calls for the professionalization of the child care worker, traditionally a person without specific aćademic or professional training. Birnback argues for their inclusion as an integral part of the treatment team, challenging the traditional distinction between psychotherapeutic and custodial functions, and describing the child care worker as "the primary therapeutic agent." (Diggles 1970, p. 509)

The organizational problems generated by the inclusion of direct care staff onto the treatment team have been adequately explored in the literature. One problem is that there are usually more direct care staff than professionals and by instituting democratic decision making the professional group would lose power. Another problem, no doubt, rises from the huge differences in authority, prestige, jab security, and salary which would tend to define professionals and direct care staff as unequal. Beavers mentions the need of all staff members for adequate income (to maintain morale), opportunity for prestige, opportunity for learning, clarity of role and praise. (1968) A third problem is that since most 
direct care staff are not screened through any training process, some individuals

' who are unprepared for responsible decision making may fill these roles.

Some authors attributed a great many of the staffs' problems in dealing with each other and with the adolescents in treatment as "failures to communicate," via "parataxic distortions," premature and inaccurate labeling, and dealings based on "distorted personifications." (Westmaas \& Westendorp 1971) It: would appear, however, that there are sociologically observed organizational and even political problems not caused by poor communication but by a conflict over authority.

A reoccuring, methodological issue is that of the necessary or optimum child/staff ratio. While Hylton found that the child/staff ratio of residential treatment facilities ranged from $1: 1$ to $5: 1$ with a mean of $2: 1$ (1974, p. 152), Taylor recommends a 1:I ratio. (1965) Beavers concludes that the staff ratio for a successful program with adolescents is higher than for any other type of program except perhaps an ambitious program for schizophrenics. (1968, p. 10)

Additional methodology issues in the residential treatment of adolescents are those of the extent and means of control and the components of program. Effective treatment of adolescents is considered to require effective controls (Nichtern 1968, p. 134), but the procedures by which control is obtained and purposes for which it is used vary. Beavers suggests that with adolescents the staff can err in two directions: by failing to be firm when the situation demands it (creating the anxiety of limits which are too loose); or by failing to create 
"the kind of comfortable equal relationship that teaches the delight of mutual problem solving." (Beavers 1968, p. 12) Adolescent patients, especially those who act out their conflicts, place severe stresses on staff relationships. (Beavers 1968, p. 12) Many facilities have some system of assigning residents to one level of a continuum of responsibilities and privileges. (Beavers 1968, p. 11) Others use a more specific point system for the modification of behavior. (Muller 1964) Authors generally agree on the need for programming activity for adolescents. Large blocks of uncommitted time are seen as undesirable and the need is recognized for sufficient workers to staff activit ies on evenings and weekends. Supplies, facilities, equipment, transportation and some financial resources are required for a good activity program. Also required is the knowledge to plan activities and recreation with potential for therapeutic benefit. Trieshman et al. (1969) urge that active programs be examined for what they give to, as well as demand of, the ego of the child. Child care workers need training on how to maximize the benefit of activities.

Provision of a school program is vital. (Beavers 1968; Gosset et al. 1973; Nichtern 1968; Maluccio 1974) Nichtern finds that most adolescents in a psychiatric hospital have a school problem of one type or another and recommends a school program which provides small classes, allows flexibility in scheduling and work assignments, and employs teachers who can work with emotionally disturbed adolescents. (1968, p. 137) Services for problem children within the public 
school system are usually inadequate, but school systems typically aid in the provision of school programs within the treatment setting.

Most treatment programs provide some form of staff training. Levy maintains that extensive and continuing inservice training is necessary to create and maintain a quality treatment program. (1971, p. 20)

Finally, methods of staff communication must be designed. These typically include written notes in individual patient charts or files, oral "report" sessions at shift changes, staff meetings designed to address administrative matters, and patient-oriented "staffing" sessions. Some systems locate the most current information on patients with case managers who may have primary responsibility for that patient for the duration of his/her residence or whose responsibility may be quite brief. "Community meetings" are typically staff-resident meetings whose topics may be primarily administrative, such as planning recreation or making changes in routine, or may move into therapeutic areas as staff and residents share their feelings about the program and each other.

The Menninger Clinic is one of a small number of programs which have their written communication in "open charts" equally accessible to staff and residents. Residents can "chart on" the psychiatrist just as the psychiatrist "charts on" them. In a system like this, there is usually a small portion of "staff only" charting for especially sensitive material. (Levy 1971, p. 21) There are other ways in which the treatment process is becoming more available to the residents of the treatment facility. Because of the recent emphasis on "contracting" for 
treatment, it has become more common for residents to have some part in deciding treatment goals and methods. Westmaas and Westendorp presented the technique called "straight talk" through which they opened up the traditional "staffing session" to the resident being "staffed", giving the resident a participantobserver role. (1971)

\section{THE FAMILY}

Every source encountered by this author made at least passing mention of the importance of working with the families of adolescents in residence. Maluccio and Marlow concur with this finding, saying that the importance of parental involvement has long been stressed by many writers. (1972, p. 236) Similarly, a study for the Child Welfare League of America concludes, "Researchers feel the findings indicate that increased work with families as a unit is appropriate and is due even greater emphasis" and that from the beginning it is important to activate strengths and provide direction for family integration. (Taylor \& Alpert 1973, p. 52)

The ways in which families are included vary. Some agencies prefer to work with children from intact families; some require court commitment for admission to residence; others insist on parental involvement, usually through casework, group therapy, or educational groups. (Maluccio \& Marlow 1972, p. 236)

Despite the concurrence of sources of the necessity for parental involvement, there appears to be a substantial gap between theory and practice. 
Maluccio and Marlow summarize, "While the goal of parental involvement in treatment is pervasive as an ideal, the emphasis in most settings is on work with the child." (1972, p. 236) They cite as evidence for this conclusion a five-year study of Rhode Island children in residential treatment which showed that generally very little work was done with the parents either by the centers or by the referral agencies. They conclude, "Few substantive articles dealing with parents have appeared. There is need for further consideration of the role of parents and particularly the factors that interfere with their more consistent and meaningful involvement." (Maluccio \& Marlow 1972, p. 236) One factor affecting parents' involvement with their children in residence is the distance parents have to travel to the treatment facility.

\section{DISCHARGE/PLACEMENT/AFTERCARE}

Discharge planning and aftercare services are among the primary problems in residential treatment. Maluccio found insufficient coordination among agencies, fragmentation of services, and inadequacy of supportive programs within the community. (1974, p. 230) The same study showed evidence that, although clear and thoughtful recommendations for aftercare services were made by the treatment institutions, there was little follow-up in the community. (Maluccio 1974, p. 233) Communities lack services. They lack the services which could have prevented the situations which require residential treatment. They lack the services which can serve as alternatives to residential treatment. They also lack the services 
which can support and maximize changes made during the course of residential treatment.

One final issue deserves mention in the discussion of residential treatment method. Quality residential treatment requires adequate facilities, furnishings, equipment and supplies. The physical surroundings need to be pleasant, comfortable and durable. Superior and detailed accounts of the manner in which facility can facilitate program can be found in Maier and Kamps (undated) and Trieshman et al . (1969)

\section{RESEARCH AND EVALUATION}

Research on residential treatment is in its infancy. Practice would be qualitatively improved by clearer understanding of the effects of various forms of residential treatment. If practitioners knew how, why and for whom residential treatment "worked," they would be able to knowledgeably alter treatment programs or more discriminately admit clients for treatment. The purpose of this section is to explore what has been discovered about residential treatment and more specifically about residential treatment effectiveness.

By far the most succinct examination of research on residential treatment is presented in the 1972 literature review by Maluccio and Marlow. They found that most research in residential treatment has been descriptive research, describing specific centers or characteristics of children in residence or program components. They found little research on the process and outcome of treatment and 
conclude, "Available studies represent isolated and fragmented efforts of individual centers and reflect the lack of cumulative research in the field of child welfore." (Maluccio \& Marlow 1972, p. 240) These authors found a need to fill the gap in research on the process of treatment and especially the factors that produce change in children. They point out that although the works of Polsky and other sociologists provide a lot of information about the interaction among residents as well as between residents and staff members, there are no conclusions about the effect (or effectiveness) of various patterns of child care. (Maluccio \& Marlow 1972, p. 241)

In summarizing their findings on the effectiveness of residential treatment, Maluccio and Marlow state that available evaluative research consists primarily of follow-up investigations focused on the relationships between adjustment in residential treatment and adaptation after discharge. They continue:

All of the available studies are descriptive, short-term and follow-up. None has the scope of a comprehensive or definitive work, each is concerned with a small number of children known to a particular center. There has been no longitudinal research, and there has not been any investigation encompassing a wide variety of treatment centers or comparing a number of programs. (1972, p. 24I)

This critiçism is echoed in the 1970 statement by the Joint Commission on Mental Health of Children which indicates that "few residential programs evaluate the outcome of their work in rigorously designed, well-controlled, scientifically objective studies." (1970, p. 273)

Two primary methodological problems are those of defining and measuring success. Success is usually viewed as the ability of the child to function 
adequately after leaving the institution. (Maluccio \& Marlow 1972, p. 241) This .definition overlooks the effect of post-institutional influences upon the resident, both supportive and debilitating. In a study of the Menninger Clinic, for example, it was determined that the degree of change achieved in residential treatment was not significantly related to post-discharge adaptation. (Taylor \& Alpert 1973, p. 45)

The measurement of successful functioning is also problematic. No single instrument stands out as capable of locating and measuring successful functioning. In 1973 one noteworthy study attempted to summarize the findings of longterm follow-up studies of adolescent residents of psychiatric hospitals. They found that thirteen studies had been published within the last thirty years. Six variables were found to be significantly correlated to the long-term outcome of persons who received in-patient psychiatric treatment. Three of these variables were related to patients: the severity of their psychopathology; the process-reactive nature of their psychopathology, and their intelligence. Two variables refer to the nature of hospital treatment: the presence of a specialized adolescent program, and completion of the in-hospital treatment. The final variable, which refers to aftercare, is continuation of individual psychotherapy following hospital discharge. (Gossett et al. 1973) Because methodological faults were apparent in the thirteen studies, the suggestion of new hypotheses for research may be the main value of this summary of their findings. 
Another interesting study, this one by Kalman Flomenhaft, compared the effectiveness of two treatment programs at Colorado Psychiatric Hospital, one an inpatient program and the other an emergency outpatient program. Adolescents from the two groups were judged on four developmental tasks of adolescence, using the Developmental Task Inventory. No significant difference was found in outcome and it was noted that outpatient treatment was both faster by a 2:1 ratio and cheaper by an 11:1 ratio. (Flomenhaft 1974)

Another important finding may be that by Grob et al., who found that while "improvement" was reported by subjects or co-respondents in 75 percent of the cases studied, intrinsic in this was a lowering of expectations which was acknowledged by the families. (1970) The most pessimistic finding, derived from a ten-year follow-up study, was that "without question" the only therapeutic variables associated with outcome were those which described the severity of illness at the time of hospitalization. (Herrara et al. 1974, p. 773)

Generally, it would appear that the field is a long way from having a workable body of knowledge on the causes of pathology, the utility of various forms of treatment, or the methodology by which to find out. There is need for comparison studies, control groups, and the replication of studies to determine the reliability and validity of various methods. The increasing insistence of funding and regulatory sources for documentation and evaluation may be incentive for attention to research. 


\section{INNOVATIONS AND ALTERNATIVES}

No literature review is complete without mention of the criticism of residential treatment and the innovations and alternatives being proposed and developed in response to those criticisms.

There are unintended consequences of institutional living. It has been described as debilitating and dehumanizing while returning few to more satisfactory levels of social functioning. (Holland 1973) Doud contends that in the hospital the patient is caught in the bind of being sick and having to admit to sickness but of not being allowed to "act" sick. (1969, p. 1745) Many persons look back on hospitalization as punitive and destructive of self-esteem. (Herrera et al. 1974, p. 773)

The decision to place a child in a residential facility often comes from the failure to provide resources for families. Resources which could be considered preventative or tertiary, are adequate income, health care, day care service, counseling, and family casework service. A more detailed presentation of this thesis can be found in William Ryan's Blaming the Victim. (1972) Ryan sees the concept of stress as the connection between poverty and mental illness. He cites the findings of Langner and Michaels, maintaining that their findings "show beyond doubt" that the more stresses a person experiences in his life, the more vulnerable he is to the development of emotional disorder. (Ryan 1972, p. 150) He continues:

Being poor is stressful. Being poor is worrisome; one is anxious about the next meal, the next dollar, the next day. Being poor is nerve-wracking, upsetting. When you're poor, it's easy to despair and its easy to lose your temper. And 
all of this is because you're poor . . . Not because [your mother] broke your bottle on your first birthday or breast-fed you until you could cut your own steak. But because you don't have any money. (Ryan 1972, p. 150)

Kahn states, "While we don't separate children from poverty stricken

parents as a matter of public policy, we do tolerate a predictable chain of events which has this inevitable consequence.". (Kahn 1966, p.7) He cites the widespread assumption that able, competent, "normal" people manage alone or obtain family help but do not need assistance from the state. The inadequacies and immorality of a small number of unfortunate citizens are assumed to produce defective children in need of treatment. (Kahn 1966, p. 7)

Kahn suggests that it means little to develop qualified foster home placements or residential treatment centers in communities which lack basic assistance programs and the related family casework or child welfare services to children in their own homes. He continues, "Otherwise poverty leads to placement, via a well-marked pathway, and the child, by the time he reaches foster care, is often disturbed." (Kahn 1966, p. 7)

It has been contended that the need for residential treatment of children could often be prevented by the provision of services to families. It has also been noted that there are often undesirable side effects of residential treatment. The main theoretical response to this dilemma, and a part of the Community Mental Health model of the mid-1960s, is the call for the development of a truly comprehensive, coordinated, and community-based network of treatment resources to meet 
the varied needs of children faced with stress and experiencing emotional problems. (Maluccio \& Marlow 1972, p. 232)

Two common recommendations are for a centralized diagnostic facility and a continuum of treatment resources.

It is proposed that

More precise criteria and centralized intake for treatment centers. in specific geographical areas could reduce inappropriate or duplicate applications, alleviate the frustrations of both centers and referral agencies, and produce more rapid and appropriate help for the troubled child. (Maluccio \& Marlow 1972, p. 240)

Adler describes a sophisticated, comprehensive, community based child placement service that emphasizes differential diagnosis and treatment planning through the use of an interdisciplinary team to match each child's need and community resources. (1969) Maluccio and Marlow, however, point out that it is difficult to make accurate diagnoses and treatment plans without strong and wellresearched theory. They state:

A frequently espoused view is that there should be differential planning for the treatment of emotionally disturbed children . . . There is a paucity of research as well as articulated theory in this area. . . Particularly lacking is comparative research into the appropriateness and effectiveness of different types of. . . . treatment. (1972, p. 239)

Kahn, too, proposes establishing centers for evaluation, referral and disposition, but he would bias them toward keeping families together. (1966)

In Oregon this trend is evident in the Pilot Program for Emotionally Disturbed Children. The goal of this program was to "identify, analyze, evaluate and integrate the needs and resources for care of the emotionally disturbed 
children in Oregon." (Oregon Mental Health Division 1969, p. 3) The documentation of service need from this project led to the establishment of seven Child Study-Treatment Centers throughout Oregon. Adolescent Study-Treatment Centers are now being proposed by the Mental Health Division. These Study-Treatment Centers are modeled after the compreherisive community based, diagnostic center proposed in the literature of the 1960s.

Two approaches are demonstrated in the development of treatment pro-. grams. One emphasis is on the coordinated availability of a continuum of nonresidential treatment resources in each community to minimize the need for residential treatment. The other emphasis is on the development of effective residential treatment resources which minimize the undesirable aspects of traditional residential treatment.

Non-residential treatment includes resources such as casework services, special school programs, day treatment centers, sheltered workshops, and outpatient therapy. It is not within the scope of this review to discuss developments in nonresidential care, except to mention that it is now more common for residential and nonresidential resources to interface and cooperate in the provision of service. Residential treatment agencies, for example, may provide casework service and family therapy for families of the residents. Psychiatric hospitals may provide day treatment programs and outpatient therapy as alternatives to hospitalization. 
New forms of residential treatment are evolving. Foster care, of course, is an established alternative to the institutional care of dependent children. A new development is special foster care, which pays a salary to the foster parents to enable them to care, for children full time. Group homes were originally developed as halfway houses to provide a gradual return to the community. They are now often seen as an alternative to institutional placement and as the treatment of choice for adolescents who are unable to return home. (Nichtern 1968, p. 42) Kahn, for example, favors agency-sponsored group homes or the smaller institutions with a relatively high staff-child ratio, a relatively small cottage grouping and with "live in" staff rather than a daily rotation of staff. (Kahn 1966, p. 9)

Sometimes agencies cooperate in the provision of treatment. A school district may provide educational resources to a treatment center. A hospital may contract to provide emergency backup for a treatment center without secure facilities and medical resources. (Nichtern 1968, p. 52) (In Oregon, the legislature has recently approved the establishment of a Secure Treatment Unit at Oregon State. Hospital for adolescents and children. Part of their mandate is to provide residential centers across the state with backup for difficult children.) Hoffman et al describe a model of community based group homes run by a child care agency which is affiliated with a psychiatric hospital with adolescent facilities (see appendix D). Considerable interaction of staff was expected since the adolescents were essentially clients of both institutions. Participating agencies had clear agreements 
about the responsibilities of each and an advisory committee was formed to establish policy and to keep the relationship dynamic. (Hoffman et al. 1975, p. 288)

In contrast to the complex and precise model above is the La Amistad program, described by Muller. The goal of this program is to provide a good, inexpensive, easily duplicable, residential treatment program for severely disturbed adolescents. (Muller 1974, p. 587) In reviewing the literature and visiting similar facilities, Muller concluded that "the most successful programs were unorthodox, had untrained residential staff, and were free of governmental controls" and that "the warmest, homiest operations operated as a family and reflected the personalities of those in charge." (Muller 1974, p. 589) He bought a small house, which was licensed, zoned, chartered, and "I.R.S. sanctioned" as a nonprofit foundation. Development of this program was relatively simple and those involved were enthusiastic about its program.

\section{SUMMARY}

In summarizing their review of the literature of residential treatment,

Maluccio and Marlow express succinctly the findings of this author:

The field is characterized by insufficient conceptual clarity, fragmentation of practice theory, and limited substantive research. Available studies, which are largely descriptive, reveal a lack of cumulative building of knowledge and experience. Crucial questions raised decades ago relative to such aspects as selection of children and the effectiveness of programs remain unanswered. (Maluccio \& Marlow 1972, p. 243)

There is evidence of evolution in the theory and practice of residential treatment. Use of the milieu and emphasis on maximizing the treatment 
effectiveness of all staff members, whatever the intra-staff pressures which result, seems to be firmly established. Emphasis on intra-psychic dynamics is waning and social learning as treatment is receiving emphasis. The importance of the present functioning of the family as a primary source of social learning is receiving greater emphasis.

There appears to be recognition that institutionalization can be regressive. The need for a continuum of treatment services and supports is commonly expressed. On the other hand, few mental health sources mention the argument of Ryan that stress from poverty causes emotional disturbance and the concern of Ryan and Kahn that the primary need is for basic services (income, housing, medical care, etc.) rather than for treatment services including preventative treatment services (parenting classes, early childhood education, teen "rap groups, " etc.)

Expansion of the treatment center into a community-based comprehensive program, and experimentation with a variety of alternatives to institutionalization, appears to have support in the literature, but establishment and maintenance of such programs now depend on financial support, primarily support through federal programs.

The chapters which follow will focus on the programming options of Woodland Park Hospital in their specific context of contingencies and restraints. It is intended that this literature review aid the staff of Woodland Park Mental Heal th Center in their consideration of issues, values, and program alternatives. 


\section{CHAPTER III}

\section{NEED FOR SERVICE}

The purpose of this chapter is to provide an overview of the need for posthospitalization treatment facilities for Portland area adolescents experiencing mental and emotional problems. This information is not presented as a definitive need assessment, but as an overview of need as it was presented by service providers. Of importance in this chapter is the defin ition of the population, or populations, in need of treatment. Also important is a broad definition of the optimum treatment modality. In later chapters program options will be more fully explored and the feasibility of establishing these programs will be considered. Some of the information for this overview was obtained from personnel at Woodland Park Mental Health Center (WPMHC). In addition, interviews were held with persons who plan, administer, and provide service to disturbed adolescents within the community.

\section{THE VIEW OF THE MENTAL HEALTH CENTER}

Consensus of the WPMHC staff is that there is a serious problem with the post-hospital placement of a number of their adolescent patients. It was the problem in locating suitable aftercare which originated this study. While exact numbers of adolescents hospitalized and subsequently placed are not available, 
independent estimates of WPMHC staff concur. Approximately fifteen adolescents are placed into residential treatrnent each month. Of these, approximately five are placed in residential situations which are inappropriate. (Wong 1976; Haley 1976) WPMHC staff outline as follows common problems in arranging aftercare:

The placement process takes too long.

Appropriate facilities have no openings for admission.

Appropriate facilities do not exist in Oregon.

Treatment recommendations requested are not followed.

These placement problems have consequences for the program at WPMHC, but more importantly, for the patients.

It appears that the delay in placement is usually a result of inavailability of appropriate treatment resources and of the time required for application and screening procedures at residential treatment programs. The delay in placing patients in post-hospital treatment when they are ready for hospital discharge slows admission into the hospital, creating a waiting list for the hospital's adolescent program.

In those cases in which appropriate treatment resources exist but have no openings for new admissions, there results either an unproductive wait in the hospital, a referral to a less than appropriate treatment resource, or an intermediate placement to await admission. Any of these courses results in some disruption of treatment in which treatment gains are diminished. The disruption may be simply a minimal irritation or may be the cause of substantial damage to the patient. 
Consensus of the hospital staff appears to be that greater treatment capacity is needed in institutions and group homes providing quality treatment programs.

For certain adolescent patients there appears to be no adequate treatment resource within the state. These patients are usually placed in a less-thanappropriate treatment setting. Some are still able to adapt and grow in the placement. For others the placement essentially provides little or no treatment. Adolescents often run away from a placement for which they are not suited.

Two of the primary services provided by Woodland Park Mental Health Center are evaluation and treatment planning. When the recommended treatment plan is not followed (perhaps cannot be followed because of the treatment setting), the value of these services is lost. Of course, this is a waste of a costly service, but of greater importance is the fact that the patient suffers from the abrupt discontinuity of treatment.

The WPMHC staff was defined three populations of adolescents for whom it is particularly difficult to find a suitable placement. These populations are:

1. Those who are dangerous to themselves, others, or property.

2. Those who are experiencing severe psychotic or neurotic symptoms which require structure, external control, and/or close medical management.

3. Those who are likely to run away from any treatment setting. The need for a "secure" treatment facility is seen as a factor in common in the programming requirements for all of these populations, but secure treatment is seen to be particularly important for the group judged to be dangerous to themselves or others. For purposes of discussion at this point, a "secure" facility may be defined 
as one which is locked and in which the opportunity for violence is minimized. Placement in a secure facility does not preclude the possibility of the resident spending unsupervised time outside the facility, but doing so is subject to doctor's. order, staff decision, or both.

Briefly summarized, the consensus of the staff of WPMHC appears to be that there is a need, for many of their patients, for easy access to a residential treatment program which will carry out the treatment recommendations of the hospital. There is believed to be a particular need for a secure facility to provide this service.

\section{THE COMMUNITY VIEW}

In order to accurately assess the need for residential treatment resources for adolescents, information and clinical judgment were sought from community sources. Existing and developing treatment resources within the community were explored. Emerging priorities, which can affect the feasibility of program ideas, were assessed. Interviews were conducted with the directors of several adolescent treatment programs and with representatives of the Mental Health Division, the Children's Services Division, and the Department of Human Resources. Community sources contacted are noted in the Bibliography. Finally, available need assessments and the Comprehensive Mental Health Plans of surrounding counties were consulted. 
In general this inquiry supported the conclusions of the hospital staff. Community sources indicate the need for additional resources for residential treatment. (Guzie 1976; Doyle 1976). An unpublished need assessment conducted by the Multnomah County Mental Health Clinic indicated that in the year preceding, responding agencies had provided residential care for 240 clients and turned away an additional 109 applicants. (Multnomah County Local Needs Assessment of Services to Families and Children 1976, p. 6) The need for adolescent group homes was one of the two most often mentioned priorities.for service. There is particular demand for secure treatment facilities, and the population defined as being in need of secure treatment appears to be essentially the same as that described by the hospital staff. The Region I Office of the Children's Services Division has been keeping extensive records of placement problems they encounter. Although the statistical computations are not complete, indications are that priority items for service are increased residential treatment capacity and, particularly, the provision of secure treatment for adolescents. (Doyle 1976)

One long awaited development is the establishment of the Secure Treatment Unit at Oregon State Hospital. This unit will provide secure treatment for fifteen adolescents from throughout the state. An additional five "crisis beds" will be used to provide emergency relief for communities and for adolescent treatment programs throughout the state. (The unit will provide equal capacity for the secure treatment of children.) Because it is anticipated that adolescents will be in residence for three to nine months or longer, none of the community sources who were 
contacted expressed the opinion that this unit will meet the demand for secure treatment resources.

The Children's Services Division has developed a description of placement resources in the Portland area. (See appendix A.) This material indicates a gap. in treatment resources for certain groups of disturbed adolescents who are considered inappropriate referrals for any of the residential centers in the area. (This material excludes hospitals.) Inappropriate for referral are those adolescents who are actively psychotic; overtly homosexual, or have an I.Q. under eighty. No indication was given in this material of the number of adolescents who are hard to place because of these reasons. The Washington County Mental Health Plan also placed high priority on the establishment of a group home for disturbed adolescents with an I.Q. below normal. (Washington County Mental Health Plan 1975)

In addition to the need for greater availability of group homes, treatment centers and secure treatment facilities, there is a small but growing demand in the community for non-residential treatment services as an alternative for disturbed adolescents. (Klesch 1976; Stern 1976; Kimmet 1976) Suggestions include alternative school programs, more flexible out-patient programs, intensive and comprehensive family therapy programs, and day treatment centers. Alternative educational programs and therapy programs for adolescents and their families both received support as priorities in the Multnomah County Needs Assessment. (1976) The Washington County Comprehensive Mental Health Plan (1975) 
indicates that the first priority for new service is more available and flexible outpatient treatment which allows mental health personnel to respond to critical situations and to see clients as often as is needed during crisis.

Adolescent day treatment is usually defined as a full five-day program which includes a school and/or vocational program, therapy, and socialization components. Day treatment is seen as a resource for post-hospital care for some and as an alternative to hospitalization for others. The 1975 Comprehensive Mental Health Plan for Clackamas County included, as second priority for service to the mentally and emotionally disturbed, an expansion of their existing day treatment program for adults. Their 1976 Plan may include a proposal for a day treatment program for adolescents. A copy of that proposal is included as an appendix of this study. (See appendix C.) In Oregon there are currently no day treatment facilities for emotionally disturbed adolescents who live at home. Oregon State Hospital does maintain an adolescent day treatment program, but participants live in a form of group home at the hospital or on hospital wards.

An additional concern within the community is the need for accurate evaluation for effective treatment planning. As one response to this concern, the Mental Health Division and the Children's Services Division are submitting a joint request to the 1976 legislature for the funding of several Adolescent Study Treatment Centers to serve as regional diagnostic facilities. There also is expressed the need for a continuum of options for care and the need for continuity of care. (Stern 1976; Hancock 1976; Kimmet 1976; Hoyt 1976) 


\section{SUMMARY}

Hospital and community viewpoints highlight many of the same problems. The hospital's problem in locating suitable placements for adolescents in their program is matched by the community's concern that there is need for increased treatment capacity. Both hospital staff and community professionals place a priority on the need for secure treatment facilities. As the community laments the unavailability of evaluation and treatment planning, the hospital staff agonizes over evaluations and treatment plans which seem to be lost or ignored. Both hospital and community are experiencing the need for continuity of service.

Dissimilar is the growing emphasis within the community on the need for a serious non-residential alternative to hospitalization. Day treatment is being pictured as a missing resource in the needed continuum of care: a potential alternative to hospitalization for some adolescents and, for others, a.posthospitalization support to ease transition back into the community.

As Woodland Park Mental Health Center considers expanding their range of services to adolescents beyond the existing inpatient program, there appear to be four options. Services can be expanded to provide secure residential treatment, nonsecure residential treatment (including group homes), adolescent day treatment, or some combination of these. In the following chapter these options will be discussed. 


\section{CHAPTER IV}

\section{PROGRAM OPTIONS}

Chapter III presented a rough overview of the need for treatment services as defined by the staff of Woodland Park Mental Health Center and by persons in the community involved with the treatment of disturbed adolescents. This chapter will focus on presenting and discussing the three treatment modalities suggested by the study of need and mentioned in discussion with service providers: (1) secure treatment, (2) non-secure residential treatment, and (3) day treatment. A model which combines two of these options will also be discussed.

In this chapter certain program components are defined as desirable or necessary for the effective treatment of disturbed adolescents. The components were so defined by a consensus of opinion expressed by WPMHC staff, community service providers, and by the literature on residential treatment. On occasion there were contradictory opinions, or components commonly judged to be required for certain adolescents, but judged to be contraindicated for others. These differences are presented and considered in the discussion which follows.

The intent of this chapter is to present a consideration of the major components of various basic treatment modalities. A discussion of program particulars (staffing patterns, admission and discharge procedures, etc.) must be derived from 
more basic policy decisions on the population to be served and the basic treatment modality.

An awareness of the constraints of feasibility is commonly present among staff and community service providers. Discussion of what is needed was blended with discussion of what is possible. Primary issues of feasibility are the availability of funds for capital expenditures, the availability of funds for purchasing care, and the requirements of licensing and regulatory bodies. Circular conversations were common, typically presenting the concern that " $X$ " form of adolescent treatment is necessary but that (a) funds are not likely to be available for required capital expenditure and that (b) the available facilities would not really accommodate the treatment format necessary to reach the population in need, and (c) there probably would be no source of funds to purchase care anyway.

To avoid circular discussions such as this one, it eventually became apparent that the most useful way to present information would be to discuss each treatment option separately in terms of its benefits and shortcomings. Both programming issues and concerns of feasibility will be addressed in the discussion of each option.

\section{SECURE TREATMENT FACILITY}

A "secure treatment facility" is commonly defined as a facility which is locked and in which the danger of violence to self or others is minimized. Medication, use of a "quiet room" or restraints may be used to control behavior. 
Placement in a secure facility does not preclude the possibility of the resident spending unsupervised time outside of the facility, but doing so is subject to doctor's order, staff decision or both. Adult clients voluntarily in treatment at a secure facility have the right to leave treatment "against medical advice, " but in Oregon, children whose parents voluntarily place them in treatment are not legally free to leave unless they have their parents' consent. The legal rights of juvenile patients are currently under consideration. (Moss 1976)

\section{Benefits}

1. It would provide the secure facility felt to be necessary or desirable for certain populations.

2. There is high demand for secure treatment in the community.

3. A treatment center could provide facilities for recreation, school program, and possible vocational training.

4. A highly developed treatment program assumes sufficient staff to carry out specific and detailed treatment programs, and to control acting-out behavior.

5. Funding is available through Title XIX directly from the Public Welfare Department if the facility is accredited as a Psychiatric facility by the Joint Committee on the Accreditation of Hospitals (JCAH).

\section{Shortcomings}

1. Would seem to require a large capital expenditure for purchasing, building, or remodeling to meet treatment requirements and fire and health codes (a major problem). 
2. A high daily cost of care is probable.

3. It is likely to be the kind of "total institution" which with an all odolescent population creates an "adolescent culture" with resulting problems.

4. The total environment is not needed for some of the adolescents with problems in placement, and would tend to be regressive.

5. Removal from the family and the community may stigmatize the adolescent. Re-entry (or the nextplacement) may be more difficult.

Discussion

A secure treatment facility would provide much of what is felt to be important to meet the need. It would provide security and extensive treatment (school, recreation, medical supervision, psychotherapy). It would not provide for the socialization needed by many, because a secure treatment facility tends to be a total institution. Funding for the cost of care seems quite likely, but capital expenditures would probably preclude the establishment of such a program unless a facility was found which required little renovation.

\section{NON-SECURE RESIDENTIAL TREATMENT (GROUP HOME)}

Two basic models of residential treatment have been suggested by WPMHC staff. The first model is the secure treatment center discussed previously. The second model, and the form most often mentioned, is the group home.

A group home for disturbed adolescents is usually located as unobtrusively as possible in a family residence. There are a small number of residents under the 
upervision of resident "house parents." Houseparents are chosen on the basis of their ability to deal with adolescents. There are commonly certain "house rules" governing behavior. The degree of structure provided by these expectations, the counsel and supervision offered by the houseparents, the support of the living group, and certain casework services, are the main elements of group home treatment. Occasionally staffing patterns differ, but the group home model of treatment is essentially as explained above.

In discussion with WPMHC staff it became clear. that there are consistent expectations that the group home could provide treatment components beyond the scope of the traditional group home model. Staff emphasize the importance of providing a school program and the need to follow specific treatment plans for each resident. The provision of a highly structured environment with strict day and night supervision is considered necessary and there is concern that a locked facility, a quiet room, or an alarm system may be required. That these components are seen as necessary for the hard to place population is not unexpected. It is not clear, however, how those components might be accommodated in the group home model. Because of this dilemma, the consideration of program capabilities is of particular importance in the analysis which follows.

Benefits.

1. There would be a smaller capital expenditure for a facility to meet stafe code for group homes than for a building termed a "residential treatment facility." 
2. The program could operate with only a small group of adolescents and easily expand by adding a second group home as needed.

3. Ahospital-run group home may possibly be eligible for some Title XIX funds if certified by the Mental Health Division as a psychiatric facility subcontracting to one or more county mental health programs.

4. Group homes usually cost less per day than institutional care.

5. A group home provides a more "normal" situation. Residents would be in greater contact with the community and thus be less institutionalized by their experience.

6. The group home would provide more opportunities for socialization than an institution providing secure care.

Shortcomings

1. It is unlikely that a set of house parents, even with support from a teaching staff or social service staff, will be able to provide the desired level of intensive care and treatment to a group of adolescents. Other staffing patterns would be more costly:

2. Children's Services Division funding is unlikely, since CSD funds for out-of-home care are limited.

3. It is unlikely that building codes would permit a group home to be locked or have a quiet room (both of which were considered highly desirable or necessary). 
4. Children's Services Division regulations require treatment of no more than eight residents in a CSD licensed facility. (More than one house may be required.)

5: A very large house would be required to provide space for school programming and other treatment such as recreation, socialization, therapy. (A school program was judged very important by WPMHC staff.)

6. Receiving CSD out of home funding would probably mean dealing with the CSD bureaucracy (red tape).

Discussion

It would be fairly easy to establish a group home. Capital expenditures would be reasonable, and finding a facility in a desirable location would probably be feasible. (WPMHC staff stress the importance of a suburban or semi-rural setting.) The cost of group home care is usually quite reasonable, and it is possible that funding might be available through CSD out of home care monies or through PWD Title XIX. It seems, however, that a group home would not provide the kind of treatment which was outlined in the section on need. It would provide neither an intensive, individualized treatment program, nor a secure facility. A group home which was more heavily staffed, perhaps staffed on shifts, would be more expensive, would lose some of the "hominess" of a group home, and would still encounter the limits of the facility. 


\section{DAY TREATMENT PROGRAM}

Day treatment for adolescents usually provides a program five days per week. It includes a school and/or vocational program, therapy, socialization, recreation, and the supervision of medication as required. Participants live at home, in group homes, or independently. For further clarification of day treatment, two models are included in the appendixes of this study. (See appendixes C and D.)

It should be remembered that the idea of a day treatment facility was not suggested by the WPMHC staff. It did, however, receive sufficient support in the literature and in the community to include it among a consideration of the options.

Benefits

1. Establishment of a day treatment program would require only a reasonable expenditure for the facility and materials.

2. The day treatment program could provide an extensive and intensive program of treatment, education, socialization, recreation.

3. Elements of day treatment are fundable through Title XIX provision.

4. A teacher or teachers could be provided through the Intermediate Education District.

5. Day treatment can function as a post-hospitalization support or as an alternative to hospitalization. 
6. For adolescents able to live at home, day treatment provides a serious, intensive form of treatment without displacing the adolescent from the home, stigmatizing or institutionalizing him/her.

7: The idea has support of policy makers in the Mental Health Division, which has Title XIX funds earmarked for alternatives to hospitalizations

8. Multiple living options provide some continuity of care and allow an adjustment to individual needs.

\section{Shortcomings}

1. Day treatment does not provide a place to live for adolescents who are in need of a place to live.

2. Day treatment is not secure.

3. A day program may not be sufficient intervention for some adolescents who need a twenty-four hour milieu.

4. Clackamas County may receive funding to establish adolescent day treatment for Clackamas County residents, thus reducing some of the demand in the Portland area for adolescent day treatment.

$\underline{\text { Discussion }}$

Day treatment seems to be able to provide a rich treatment program for those adolescents who already have a place to live either at home or in a foster home or group home. It is flexible, encompassing both the need for post-hospital support and the need for an alternative to hospitalization. Its flexibility would 
allow it to provide continuity of care for an adolescent moving through a conrinuum of living situations. The main problems with a day treatment program attempting to serve the needs of the identified population are the fact that the program does not provide a place to live or secure treatment.

\section{A FOURTH POSSIBILITY}

Somewhere in the midst of deliberations on the dilemma presented by three less-than-ideal options for a treatment model, it became apparent that there was another option not mentioned by any of the sources. This option is a combination of the day treatment program and the group home program. A combination of these two models appeared to eliminate most of the major deficits of each. In a combined day treatment-group home model, the core of therapy and education would be carried by the day treatment program which would be supplemented by residence in a hospital-affiliated group home for those in need of a therapeutic living situation. A detailed model of inter-agency provision of group-home-hospital treatment is presented by Hoffman et al. (1975) (See appendix D.) The analysis of benefits and shortcomings of the day treatment-group home model follows. 
DAY TREATMENT/GROUP HOME

\section{Benefits}

1. Initial costs for facilities and materials would be moderate.

2. A combination of funding sources may be possible.

3. An extensive treatment program could be provided without removing the adolescent from community contact (resulting in less regression and stigmatization than residential treatment).

4. Options for residence without the loss of the support of the day treatment program would provide for a continuum of care within the hospital program.

5. The Day Treatment/Group Home model could function as a posthospitalization support for some and as an alternative to hospitalization for others.

6. Woodland Park Mental Health Center could act as a "back up" when there was a need for secure treatment.

7. Although day treatment for adolescents is a very new concept in this state, some existing programs could provide models for the establishment of a day treatment/group home program. These include: the Adolescent Treatment Program at Oregon State Hospital, JANIS, which has an alternative school program and a number of group homes, and the Psychiatric Day Treatment Program at the Child Development and Rehabilitation Center--a program for children which includes significant work with families and with schools to which the children return. 
Shortcomings

1. It would not provide secure treatment.

2. There could be problems in communication and role clarity between the group home staff and the day treatment staff.

3. Sources of funding are not clear at this time.

Discussion

This program option appears to be financially feasible if funds for the cost of care can be arranged through Title XIX monies (and/or CSD out of home money). The cost to establish the program would appear to be reasonable. This model could provide an extensive treatment program, not the least of which could be the social learning of the group home experience. It would be important that the group home be utilized as part of the total treatment rather than viewed as simply a place to board adolescents when they are "not in treatment."

The main problem with this program option is that it does not provide secure treatment. It would be possible to arrange fairly close supervision and structure, but. not secure treatment.

\section{SUMMARY}

Four program options have been considered in this chapter. Before it is possible to further develop a program plan, a policy decision needs to be made as to which program option to pursue. To this author, there appear to be two program options which address the needs of the identified population: (1) a secure 
residential treatment institution and (2) a day treatment/group home program.

While there appears to be great demand for secure treatment, the cost to build or remodel a facility seems prohibitive. A day treatment/group home model, while initially appearing to be a bit unwieldy, would appear to be worthy of consideration. 


\section{CHAPTER V}

\section{SUMMARY AND CONCLUSIONS}

This study was requested to aid the staff of Woodland Park Mental Health Center in exploring options for the expansion of their treatment services for adolescents. In particular, this study has been addressed to the needs of adolescents for whom it is difficult to locate adequate residential treatment resources for posthospital placement.

Information was gathered on (1) the need for residential treatment resources, (2) alternative models for treatment programming, and (3) the feasibility of establishing and maintaining a residential treatment program. Sources of this informa-. tion were staff members working with adolescents at Woodland Park Mental Health Center, a wide range of planners and providers of mental health services to adolescents, and the literature on treatment.

There appear to be two populations experiencing placement problems. Individuals in the first population are appropriate for one or more of the existing child care centers or residential treatment facilities but experience delays while waiting for an opening at an appropriate facility or while the admission process is completed. If no openings occur in appropriate treatment programs they may be placed in a less-than-appropriate program. They may experience abrupt 
discontinuity of treatment if treatment plans derived from hospital evaluation are not followed.

Few treatment resources exist for the second population comprised of (1) those who are dangerous to themselves, others, or property, (2) those who are exhibiting severe and debilitating psychotic or neurotic symptons, or (3) those who are likely to run away from any treatment setting at the time of hospital discharge. A secure treatment facility is seen as necessary for optimum treatment of this second population.

Staff of Woodland Park Mental Health Center recommended or discussed two models of treatment facility. The first is the secure treatment facility, the second is a group home with extensive treatment programming. Community sources contacted by the author confirm the need for secure treatment resources and for increased group home capacity, but maintain that there also exists a need for adolescent day treatment services.

Four treatment models were considered in light of what components of treatment programming each would provide and whether it would be feasible to establish and maintain that kind of treatment facility at this time. It was concluded that two options should be given further consideration, a secure treatment facility model and a day treatment/group home model:

This study will be presented to Dr. Korman, administrator of Woodland Park Mental Health Center. It is recommended that the study then be made available to the adolescent treatment team, and that the four options be presented and 
discussed at a team meeting. Out of a consensus of the team, a recommendation should be made to Dr. Korman whether to further consider the development of the treatment models presented. 



\section{SOURCES CONSULTED}

Abend, Sander M.; Kachalsky, Hyman; and Harvey R. Greenberg. "Reactions of Adolescents to Short Term Hospitalization," American Journal of Psychiatry, July, 1968, 124 (7).

Adilman, Phillip H. "Some Concepts of Adolescent Residential Treatment," Adolescence, winter, 1973. 8 (32)

Adler, Jack. "General Concepts in Residential Treatment of Disturbed Children, " Child Welfare, November, 1968.

- "Diagnostic Considerations in Community Planning for Residential Treatment," Child Welfare, June, 1968.

Ananda, Mary. Tualitin Valley Clinc, Beaverton, Oregon. Interview, 7 May 1976.

Beaver, Steven R. Woodland Park Mental Health Center, Portland, Oregon. Interview, 5 May 1976.

Beavers, W. R. "Managing Adolescent Inpatients," Hospital and Community Psychiatry, 1968, January, 19 (1).

Birnback, David. "The Skills of Child Care" in The Practice of Group Work, William Schwartz and Serapio R. Zalba, eds., New York: Columbia University Press, 1971.

Browne, Clifton T. "Some Problems of Children's Institutions in Achieving Maturity," Child Welfare, February, 1963.

Carey, Bill. Children's Services Division, Salem, Oregon. Interview, 19 April 1976.

Child Welfare League of America. Standards for Services of Child Welfare Institutions, New York: Child Welfare League of America, 1964.

Clackamas County Mental Health Program. "Comprehensive Mental Health Plan," 1975. (mimeographed) 
D'Amato, Gabriel. Residential Treatment for Child Mental Health, Springfield, Illinois: CharTes C. Thomas, 1969.

Dettelbach, Mirian H. "Criteria for Agency Referral of a Child to a Residential Treatment Center," American Journal of Orthopsychiatry, October, 1955.

Diggles, Mary W. "The Child Care Counselor: New Therapist in Children's Institutions," Child Welfare, November 1970.

Doud, Robert M. "The Impact of Patient-Staff Social Structure on the Treatment of Adolescent Patients in a Mental Hospital, "Dissertation Abstracts International, April, 1969, $30(5-\mathrm{A})$.

Doyle, Jo Anne. Region I Office of the Children's Services Division, Portland, Oregon. Interview, 7 May 1976.

Eggars, Karen. Oregon State Hospital Day Treatment Program, Salem, Oregon. Interview, 25 May 1976.

Flomenhaft, Kalman. "Treatment of Emotionally Disturbed Adolescents," Dissertation Abstracts International, February, 1971, 31 (8-A).

- "Outcome of Treatment for Adolescents," Adolescence, Spring, $1974,9(33)$.

Fry, Lincoln J. and John P. Miller. "The Impact of Interdisciplinary Teams on Organizational Relationship," Sociological Quarterly, March, 1974, $15(3)$.

Garrison, Jim. Washington County Children's Services Division, Beaverton, Oregon. Interview, 10 May 1976.

Glickman, Esther. Child Placement Through Clinically Oriented Casework, New York: Columbia University Press, 1957.

Gossett, John T.; Lewis, Susan B.; Lewis, Jerry M. and Virginia A. Phillips. "Follow-up of Adolescents Treated in a Psychiatric Hospital: I. A Review of Studies," American Journal of Orthopsychiatry, July, 1973, $43(4)$.

Grob, Mollie; Edinburg, Golda; Stanton, Alfred H. and Norbett Mintz. "From Psychiatric Hospital to Community: What Happens to the Adolescent Patient?" American Journal of Orthopsychiatry, 1970. 
Grob, Mollie C. and Judith E. Singer. Adolescent Patients in Transition: Impact and Outcome of Psychiatric Hospitalization. New York: Behavioral Publications, 1974.

Guzie, Fran. Multnomah County Children's Services Division, Portland, Oregon. Interview, 7 April 1976.

Hatey, Mike. Woodlanid Park Mental Health Center, Portland, Oregon. Interview, 3 March 1976.

Hancock, Guy. Albertina Kerr Children's Center, Portland, Oregon. Interview, 24 March 1976.

Herrera, Elizabeth G.; Lifson, Betty G.; Hartman, Ernest and Maida H. Solomon. "A 10 Year Follow-up of 55 Hospitalized Adolescents, ". American Journal of Psychiatry, July, 1974, 131 (7).

Hoffman, Lee. Parrott Creek Boy's Ranch, Oregon City, Oregon. Interview, 16 March 1976.

Hoffman, Linda R.; Lehman, Virginia and Eli D. Zer. "A Group Home-Hospital Treatment Model for Severely Disturbed Adolescents." Child Welfare, April, 1975.

Hoffman, Pat. Multnomah County Mental Health, Portland, Oregon. Interview, 8 April 1976.

Holland, T. P. "Organizational Structure and Institutional Care," Journal of Health and Social Behavior, March, 1973, 14 (3).

Hoyt, Mary. Mental Health Division, Salem, Oregon. Interview, 18 February 1976.

Hrebiniak, L. G. and J. J. Alutto. "A Comparative Organizational Study of Performance and Size Correlates in Inpatient. Psychiatric Departments," Administrative Science Quarterly, March, 1973, 18 (3).

Hylton, Lydia F. The Residential Treatment Center: Children, Programs and Cost, New York: Child Welfare League of America, Inc., 1964.

Inglis, Dorothy. "Authority and Reality in Residential Treatment," Child Welfare; June, 1964. 
Joint Commission on the Mental Health of Children. Crisis in Mental Health: Challenge of the 1970's. New York: Harper and Row, 1969.

Jones, Elizabeth. Woodland Park Mental Health Center, Portland, Oregon. Series of interviews, March 1976-May 1976.

Juve, Jerry. Clackamas County Mental Health Program, Oregon City, Oregon. Interviow, 4. May 197.6.

Kadushin, Alfred. Child Welfare Services. New York: Macmillan Co., 1967.

Kahn, Alfred J. "The Social Scene and the Planning of Services of Children," Social Work, March, 1966, 7 (3).

Kamada, Dan. Woodland Park Mental Health Center, Portland, Oregon. Interview, I March 1976.

- Kanner, Leo. "Emotionally Disturbed Children: An Historical Review," Child Development, March, 1962.

Kimmett, Yvonne. Clackamas County Mental Health Program. Interview, 23 March 1976.

King, Robert. Secure Treatment Unit Oregon State Hospital, Salem, Oregon. Interview, 26 March 1976.

Klesch, Marilyn. Region I Office of the Mental Health Division, Portland, Oregon. Interview, 5 May 1976.

Korman, Ira. Woodland Park Mental Health Center, Portland, Oregon. Series of interviews, October 1975-May 1976.

Leonard, C. F. "What Helps Most About Hospitalization?" Comprehensive Psychiatry, April, 1973, 14 (4).

Levy, Edwin Z. "Long-term Follow up of Former Inpatients at the Children's Hospital of the Menninger Clinic, " American Journal of Psychiatry,

December, 1969, 125.(12).

- "Inpatient Treatment for Troubled Adolescents, " Menninger Perspective, April, 1971, 2 (3).

Lerner, Samuel. "The Diagnostic Basis of Institutional Core for Children, " Social Cosework, March, 1952, 33. 
Lindsey, Duncan. "Adolescent Pathways to Residential Treatment: The Enforced Expedition," Adolescence, Spring, 1974, 9 (33).

Lowther, William. Public Welfare Department, Salem, Oregon. Interview, 28 May 1976.

Maddock, Richard C. and Charles T. Kenny. "Staff and Resident Attitudes in Two Chilar'Care Institutions Observed Respectively, as Defensive and Participative in Their Management Practices, "Journal of Psychology, November, 1972, $82(2)$.

Maier, Henry W. "Residential Treatment," Encyclopedia of Social Work, Harry L. Lurie, ed. New York: National Association of Social Workers, 1965.

Maier, Henry W. and Franz X. Kamps. "Consultation Report on the Proposed Marin County Residential Treatment Center, " undated (mimeographed).

Maluccio, Anthony N. "Residential Treatment of Disturbed Children: A Study of Service Delivery," Child Welfare, April, 1974, 53 (4).

Maluccio, Anthony N. and Wilma D. Marlow. "Residential Treatment of Emotionally Disturbed Children: A Review of the Literature, "Social Service Review, February, 1972, 46 (2).

Mancini, Richard. Clackamas County Planning Commission, Oregon City, Oregon. Interview, 30 March 1976.

Mayer, Morris L. "The Role of Residential Treatment. for Children: Introduction," American Journal of Orthopsychiatry, October, 1955, 25.

McDowell, Richard L. "An Evaluation of a Residential Treatment Program for Adolescents as Measured by Post-Hospital Adjustment: A Follow-up Study," Dissertation Abstracts International, 1970, 30 (7-A).

Menninger Foundation. Disturbed Children, San Francisco: Jossey-Bass, Inc., 1969.

Moss, Alice. Clackamas County Mental Health Program, Oregon City, Oregon. Interview, 4 May 1976.

Muller, Walter J. "La Amistad: Starting an Inpatient Program for Severely Disturbed Young Adults," Hospital and Community Psychiatry, September, 1974, 25 (9). 
Multnomah County Mental Health Program. "Comprehensive Mental Health Plan," 1975 (mimeographed).

Nichtern, Sol. Mental Health Services for Adolescents: Proceedings of the Second Hillside Hospital Conference, New York: Frederick A. Prager, 1968.

Oregon Mental Health Division. "Pilot. Program for Emotionally Disturbed Children," February, 1969 (mimeographed).

Russel, Lucille. Children's Services Division, Solem, Oregon. Interview, 28 May 1976.

Ryan, William. Blaming the Victim, New York: Vintage Books, 1971.

Silva, Jean. Multnomah County Department of Human Resources, Portland, Oregon. Interview, 8 April 1976.

Smith, Mike. JANIS Program, Portland, Oregon. Interview, 5 April 1976.

Stannard, D. L. "Ideological Conflict on a Psychiat ric Ward," Psychiatry, May, 1973, 36 (2).

Stern, Tom. Mental Health Division, Salem, Oregon. Interview, 27 April 1976.

Sutherland, John. Woodland Park Mental Health Center, Portland, Oregon. Series of interviews, October 1975-May 1976.

Taylor, Delores A. and Stuart W. Alpert. Continuity and Support Following Residential Treatment, New York: Child Welfare League of America, 1973.

Taylor, Eugene. "Needed Services for Severely Emotionally Disturbed Children in Oregon: A Report to the Mental Health Planning Board, " 1965 (mimeographed).

Trieshman, Albert E.; Whittaker, James K. and Larry K. Brendtro. The Other 23 Hours, Chicago: Aldine Publishing Company, 1969.

Van Scoy, Holly C. and Karen J. Bordelon. "Patient's Perceptions of the Residential Treatment Staff: Revisited," Adolescence, Summer, 1974.

Washington County Mental Health Program. "Comprehensive Mental Health Plan," 1975 (mimeographed). 
Weiner, Irving B. Psychological Disturbance in Adolescence, New York: Wiley and Sons, 1970.

Westmaas, R. and F. Westendorp. "Straight Talk: An Approach to Team Treatment on an Adolescent Unit," Adolescence, Winter, 1971, 6 (24).

Wilkes, J. R. "Involving Parents in Children's Treatment," Canada's Mental Health, January-February, 1970 (18).

Wilson, Phil. Adolescent Treatment Program, Dammasch State Hospital, Wilsonville, Oregon. Interview, 19 March 1976.

Wong, Dennis. Woodland Park Mental Health Center, Portland, Oregon. Interview, 4 February 1976.

Woodland Park Mental Health Center. "Social Organization and Adjustment Program for Children and Adolescents," 1976 (mimeographed). 
APPENDIX A

PURCHASE OF CARE PLACEMENTS THROUGH CHILDREN'S SERVICES DIVISION 
STATE OF OREGON

Branch Managers, Superv1sors, Caseworkers CSD Regton I

FROM.

Linda Kogan, Supervisor

Llalson Unit, Resource Branch

\section{NTEROFFICE MEMO}

DATE: Decẹaber 10, 1975

SUDJECT:

PURCHASE OF CARE PLACENENTS

Caseworkers in my unit carry lialoon asignmente to 13 private agencies and $B$ child care center programs. The programo are described below. This memo will outline placement resources avallable through my unit, referral procedures, and liaison reaponatbilities once the child is in care.

I. Description of Resources

1. Albertina Kerr Homes (Loulbe-Tucker Cottage)

722 N.E. 162nd Avenue

Portland, Oregon 97232

233-5247

Population Served:

Loulse Home: 45 dellaquent or emot lonally disturbed g1rle 13-18, plus an aftercare group home for 4 girle. Common behavioral problems at time of referral include run away, out of control, school difficultes, shoplift, drug or alcohol abuse, promisculty.

Tucker-Cotcage: 7 severely enotlonally diaturbed boys, ages 10-13. Coumon behavioral problews at time of referral include truancy, adjudicated delinquency, chronlc runavay, lnabllity to form relationships. Specialized Fouter Care: 13 children who were released to Albertina Kerr for adoption but are unadoptable because of phyolcal or emotional hand1capa. These chlldren are supervised and cared for by Albertina Kerr foster parenta and staff. We do not refer CSD children to this program.

Inappropr 1ate Referrals:

Loulse Hone: I.Q. under 80, actively paychot1e, houlc1del, overtly homosexual

Tucker: I.Q. under 90

School:

Both programe use Wynne Wate, a residential school located on the campus. Wynne Watts avallable to othere on a linited basis.

\section{Progran Components:}

boulse: Residential treatment center for $45 \mathrm{girla}$ who live in three dorms of 15 each. Treatment model 10 mileau therapy. Fandly therapy is offered if appropriate, ut1liziag mitiple Impact therapy. Average length of stay 1812 - 14 months. Loulse operates one group houe for aftercare. Purchase of care wonthly paywent 10 $\$ 849.43$ per ch1ld.

Tucker: A locked, structured cottage for 8 boys who cannot be treated in an open letting. Treatment podel lo token econowy, behavior modification. Average length of stay 1o lik years. Purchase of care monthly cost is $\$ 1,953.22$ per ch1ld. 
December 10, 1975

Page 2

Referral Process:

Send 147 to Resource Branch. Diacusa the referral with the CSD Lialaon Worker. If the referral 1s appropriate, a social summery Including any poychological and paychiatric data avallable should be sent to Loulse with a copy to the liaison worker. Tucker referrals should be addressed to Jul1e Plekan.

2. Boye and Girls A1d Society of Oregon

2301 N.W. Gl1san Street

Portland, Oregon 97210

222-9661

Population Sqryed:

32 childzen $0-18$ in need of specialized foster care. Pregnant wom of any age may also be referred with1n the 32 slots. Referrals must be children who would require special rate foster payments if placed in CSD foster hones for example, children with severe phyalcal or emotlonal probleme or retarded children. Pregnant women in need of out-of-home care and counseling may also be referred.

Inappropr 1ate Referrals:

Ch1ldren who cannot be maintained in foster or group hose placementa.

School:

Boys and G1rls A1d has a small resident 1al school at their headquarter: which is used primarily for their pregnent clients.

Program Componente:

Boys and Girls Ald social workers provide casework services to foster tanlly howes and individual counseling to children in care. About half of Boys and Girle Ald population are children wo were released at birth to the agency but were unadoptable and are grouring up in long-term forter care. Length of stay for children. referred by CSD varles according to the case plan. Purchase of care wonthly cost 1s approximately $\$ 632.88$ per ch1ld.

Referral Process:

Discuss the referral with the CSD Lialson Worker. If the referral in appropriate, send a social sumary to the agency with a copy to the lialson worker.

3. Cathollc Services for Ch1ldren

700 Loyalty Bullding

317 S.W. Alder Street

Portland, Oregon 97204

228-6531

Cathollc Services operates a speclalized foster care program and three ch1ld care center programs.

Specialized Fogter Care:

Population Served:

45 children $0-18$ in need of specialized foster care. Referrals ausc be 
Decenber 10, 1975

Page 3

clitidren sho would require special rate foster payaents if placed In a CSD foster home; for example, children with severe phyalcal or enotional problems or retarded children.

Inappropr 1ate Referrals:

Children who cannot be malntained in fostet or group home placements.

School:

ChIldren wat attend public school.

Program Components:

Catholic Services social worker provide casework services to foster faily homes and individual counseling to ch1Idren in care. About 1/3 of Catholic Services population are ch1ldren who were released at birth to the agency but vere un-adoptable and are growing up in long-tern foster care. Length of otay of children referred by CSD varles according to case plan. Purchase of care wonthly cost 1. $\$ \$ 10.88$ per ch1ld.

Referral Procegs:

After discuesing the referral with the CSD Lialson Worker, a social sumary need to be sent to Orv Garrieon at Cathollc Services.

\section{Child Care Center Program:}

Carroll House

3725 S.E. $80 \mathrm{th}$

Portland, Oregon

Multnowah Boye Center

451 N.H. let

Greshan, Oregon

Seeghers House

9225 N.W. Leahy

Portland, Oregon

Population Served:

Carroll House: 10 delinquent or emotlonally dieturbed boye 11-18; age

for new referrals 11-16. Common behavioral probleme at time of referral

lnclude runaway, out of control, school problews including truancy,

adjudicated delinquency.

Multnomah Boys Center: 10 delinquent or emotionally disturbed

g1r1s, ages 11-18; age for new raferrals 12-16. Coweon behavioral

probleas at time of referral lnclude runaway, out of control, truancy,

alnor del inquency.

Seeghers Houge: Texporarily closed while reprogramang to serve

11-18-year-old slov boys with behavioral probleme. Should ba operational. in February or March, 1976.

Inappropr 1ate Referrals:

Carroll Houge: I.Q. Under 80, actively psychotlc, dangerously

acsaultive or violent, overtiy homosexual, cannot be malotained

in public echool. 
December 10,1975

Rage 4

Mifinopah Boys Center: I.Q. under 80, actively poychot1c, dangerously ascaultive or,violent, overtly homosexual, cannot be maintained in public achool.

School:

sut be able to attend public school.

Program Components:

Carroll House and Multnomah Boys Center are communty based programe

wth a house parent model. Individual and group treatment are offered.

Doth programs have a atem of increasing privileges and responsibility by levels. Both work with familles when parents are a resource. Average length of stay 1s 9-12 months. Purchase of care monthly cost is $\$ 741.61$ per child.

\section{Referral Process:}

Discuse referral with the CSD Liaison person to deternine if

Catholic Services 18 the most appropriate placement. The lialson

worker will then eicher arrange an intake ataffing or place the

147 on the child care center walting list unt 11 a vacancy occurs.

Child care center gtaffings are generally held at the facility

ind attended by Catholic Services staf, the child and his family,

the referring caseworker, and the liatuon worker. A gocial sumbry needs to be sent to the Cathollc Services at the time of the intake stafing with a copy of the referral letter sent to the, CSD Liaigon Worker.

4. Christie School

Marylhurst, Oregon 97036

635-3416

\section{Papulation Served:}

35 enot lonally disturbed g1rls, 9-16, 9-13 at time of referral. Typically not beyond $8 \mathrm{th}$ grade at time of referral. Comnon behavioral problems at the time of referral include: lying, stealing, disuptive behavior in school and howe, trunncy, sexual activity, runavay, learning problems.

\section{Inappropr 1ate Referrale:}

I.Q. under 80 , actively paychotic, honicidal or dangerously assaultive, aufidal, runaway when very "streetwige", Inability to relate when in the upper linit of age range.

School:

A residental school is located on the canpus. Some girls go out dally to public school.

\section{Progran Components:}

Redidential treatment program for $35 \mathrm{~g} 1 \mathrm{k}$ s who live in two large living units housing $6 \mathrm{girls}$ in each of 6 wings. Treatment wodel is mileau therapy. Individusl and group counseling 1o offered. Christie 
Decenber 10, 1975

Page 5

coctal workere work with fanllies when appropriate. Average length of etay 1e it - 2 yeare. Chrietie al wo operates one group home. Purchace of care anthly cost 10 $\$ 968.38$ per chlld.

\section{Referral Process:}

Diecuse the referral with the CSD Lialeon Worker. If the referral is appropriate, send a social sumary uaing the Chriatie refartal information outline attached. Send a copy of the referral to the 11a1eon worker.

5: Ch1ldren's Ferm Howe

4455 M.E. Highway 20

Corval11e, Oregon 97330

752-5105

\section{Populat 1on Served:}

39 boye and $10 \mathrm{~g} 1 \mathrm{rls}$, ages 12-18, tho are emotlonally dieturbed or delinquent. Comon behavioral probleme at the time of referral include runavay, out of control, school problens Including triancy, adjudicated delinquency, inpuleivity, 1solation, drug or alcohol abuse.

\section{Inappropriate Referrale:}

I.Q. under 85, actively psychotle, houleldal, overtly.homosecual, cexually acting out girle.

\section{School:}

Realdential school located on the cempus staffed by Corvallia School Syater.

\section{Prosran Componente:}

Realdential treatment progran loceted out of Corvallia. Co-ad progran conalate of 3 living unite of boye of 12-15 each and 1 for girls with maximus of 10 . Treatment model is mileau therapy with individual and group counseling avallable. Average length of stay is lis to 2 . years. The Farm Howe operates a boya' group how for aftercare. Purchnes of care monthly cost is $\$ 882.98$.

\section{Referral Process:}

Dincuse the referral with the CSD LInieon Worker. If the raferral 10 approprinte, eend a social rumary ualing the Parm Howe referral Information outline attached. Send a copy of the referral to the liadeon worker.

6. Edgetield Lodge

Doute 2, Box 61

Troutdale, Oregon 97060

665-0157

Population Served:

Resident 1al: 14 coot 10nally dieturbed children 6-10. who realde at 
December 10, 1975

Page 6

Edgefleld Lodge 5 days per week and in the communtty on weekends. Comson behavioral problems at the time of referral include lylag, stealing, bed wettings, disruptive behavior in achool and home.

Day Treatment: 28 emotionally disturbed children, ages 6-10, whose behavior causes problem. in public school and in their homes.

Out Patient: 35 emotionally disturbed children of any age.

Both the parents or foster pareats and the child wust be able to use the child management and parenting ak1lls offered by Edgefield staff.

\section{Inappropr 1ate Referrals:}

I.Q. under 80 , actively paychot 1c, chlldren who do not have workable fanllea or a foster fanily resource. For the outpatient program, chlldren wust have stronger ties to thetr famllies than to their peer eroup.

School:

Residential school 18 avalfable on Edgefield's campus for children in the day treatment and residential programs. The school emphasizes behavior modification - token economy techniques.

Progran Components:

Edgefleld offers intensive treatment for emotionally diaturbed children and their families ut1lizing a eophisticated behavior modification and token economy system. School and residential living programs are closely coordinaced. There 1s a major emphasis on providing parenting and child management skills to parents or foster parenta prior to the child's graduation and on providing follow-up service after graduation. Average length of stay 1s 9-12 months for residential and dey treatment and 3-6 wonths for out patient. Purchase of care monthly cost per ch1ld 1s $\$ 574.01$ out pat lent, $\$ 971.73$ day treatment, and $\$ 2,001.11$ resident1al.

Referral Process:

After discusaing the referral with the CSD Llalson Horker, the caseworker must have the parents or foster parents call the Intake Department at Edgefleld directly. Edgefield is the only agency which does their own extended intake directly with the client. They may not request a social sumary from CSD in all cases.

7. The Inn Home

3033 N.E. Bryce

Portland, Oregon

282-1545

\section{Population Served:}

Seven boys between the ages of 12-17, age at time of referral 12-16. Compon behavioral problems at the time of referral include runaway. 
Decerber 10,1975

Page 7

out of control, school problems including truancy, adjudicated delinquency.

Inapproprlace Referrale:

Actively paychotic, dangerously assaultive or violent, overtly hososexusl, cannot be intained in public school, fire setters, and I.Q. under 80 .

School:

rust be able to attend public achool or alternate school. Boys attend Grant or Adams High School, Alameda Grade School and Open Meadows.

\section{Progra: Components:}

The Inn 1s a community based prograin with a combination live-in and shlft staffing model. Individual and group treatment are offered. The treatment model $1 \mathrm{~s}$ eclect ic with emphasig on behavior modification point systein for privileges and Individual contracts to work on Identified problems. Counselors work with familles when parents are asource. Average length of stay is 1 year to 15 months. Purchsee of care monthly cost 1s $\$ 780.80$.

\section{Referral Process:}

Discuss referral with the'CSD Liaison person to determine if the Inn is the most approprlate placement. The l1aleon worker will then either arrange an Intake staffing or place the 147 on the chlld care center walting 11 st unt 11 a vacancy occurs. Child care center ataffings are generally held at the In and attended by Inn staff, the child and his family, the referring caseworker and the liaison worker. A social sumary needs to be sent to the Inn by the time of the intake staffing with a copy of the referral letter sent to the CSD Lialson worker.

8. Parry Center for Ch1ldren

3415 S.E. Powell Boulevard

Portland, Oregon 97202

234-9591

\section{Population Served:}

48 ser lously emotionally disturbed children, ages 6-17; age at time of the referral 6-10. Common problema at tine of referral include diaruptive behavior at howe and school, lying, acealing, bed wetting, serlous syuptoms of enotional disturbance such as solling, tuding food, open anturbation, crueley and violence. Autistic and psychotic children ara appropriate referrala.

\section{Inappropr late Referrals:}

I.Q. under 80, Inability to relate in older children. Will consider lower I.Q. If it appears to be functional rather than organic. 
Decenber 10,1975

Page 8

School:

Realdent1al school on campue. Soee children go out dally to public achool.

Progran Components:

Children live in units of no more than 10 each. Treatment model is alleau therapy. Individual and group therapy are avallable. Parry Center works with familles when appropriate. Average length of atay varies according to the treatment plan but 1s usually around 2-4 yeara, which 18 longer than at most other agencles. Parry Center operates two group hosee for children able to leave the institution. Purchaee of care wonchly paywent 1s $\$ 1,306.32$ per ch1ld.

\section{Referral Procese:}

Discues the referral with the CSD Lialson worker. If the referral 1. approprlate, send a detailed social sumary including poychological or paychiatric data to Parry Center with a copy to the liainon worker. See attachment for referral informetion guide.

9. Providence Child Care Center 830 N.E. 47 th Avenue

Portland, Oregon 97213

234-9991

\section{Population Served:}

52 phyalcally and/or mentally handicapped non-ambulatory ch1ldren tho require skilled nursing care. Children at Providence commonly have serloue medical problems such as congenital deformities, hydrocephalus, microcephaly, and/or ecvere retardat ton. Fany are terminally 11l. Providence 1s the only epecialized children's nureing hoes facility in the state.

\section{Inappropr1ate Referral:}

Children who are ambulatory, who do not have a diagnoale which necessitates akilled or aemi-okilled nursing hose care and who are larger in olze than will fit into a $60^{\prime \prime}$ crib.

School:

The aijority of the children are not educable. I.E.D. places children In education programe when the children are able to une auch programe.

\section{Pronran Components:}

Children reside in 3 wings at the facility. A very good physical cherapy unit is avallable. The progran offers skilled and sealokilled nursing home care, social work services, and phyalciane' services. The Providence social worker worke with familles and plane after care in conjunceion with CSD. Purchase of care monthly cost is funded 
3 waye: (1) $\$ 20.64$ per day 1s pald by P.W.D. (2) If eligible, 5.5.I. paye $\$ 25.00$ per month for pereonel incidentals. (3) CSD paye $\$ 20.20$ per month fee Social Services and $\$ 10.54$ per month for personal incidentale for children not eligible for S.S.I.

Referral Rrocess:

After diecusaing the referrai with the CSD L1aieon worker, call

Mra. Carroll at Providence. Referral mat include medical documentation of the need for nursing home care and a social sumary. Send a copy of the written referral to the Ila1eon worker.

10. St. Mary's Home for Boya

16535 S.W. Tualitan Valley Highway

Beaverton, Oregon 97005

649-5686

Population Served:

42 delinquent boys or emotionally disturbed boys 9-15 years old. Comon behevioral problems at the time of referral include run away, out of control, severe school probleme lacluding truancy. dieruptive behavior, poor impulse control, adjudicated delinquency.

\section{Ineppropriace Referrals:}

I.Q. under 80, actively poychot1c, dangerously aesaultive or violent, overtly howosexual, hlotory of fire setting.

\section{Schiool:}

5t. Mary'o has a residential scbool on campus which uses a behavior sodification token econouy oystem and 1s closely coordinated with the overall program. Some boye go out to publlc school on a dally base.

\section{Program Components:}

St. Mary's is a reoldential treatment center with two large cottage living units for 20-25 boys each. The primary treatment modality 1a a behavior modification token economy unetem which is tied in to a levels syoten. Work with parents is avallable on a very limited basis and only when the parentg are villing to come to St. Mary's for coungeling. Average length of otay is 1-2 years. Purchace of care monthly cost 1o $\$ 852.17$ per ch1ld.

\section{Referral Procees:}

D1ecuse the referral with the CSD 11aieon worker. Send a bocial wuranry to St. Mary'. with a copy to the llaieon worker, uelag the St. Mary's referral outline (See attachment). Note that St. Mary' requires a WIS vith subtest scoree and detalled school information. 
December 10, 1975

Page 10

11. V111. St. Rone

597 North Delaum Street

Portland, Oregon 97217

285-3030

Populacion Served:

47 delinquent or enot lonally diaturbed g1rls 13-18. Common behavior problems at the time of referral include runaway, out of control, poor impulse control, school difficulties, shoplifting, alcohol or drug abuge, promiscuity, hostile or deflant attitude toward authority.

Inappropr 1ate Referral:

I.Q. under 85, actively psychotic, homicidal, overtly howosexual.

School:

V111a oparates a rasidential achool on caupus.

\section{Program Components:}

Villa operates a structured residential treatment program ut1lizing mileau therapy. Girla reside in two large living units. Both Individual and group counseling are avallable with a heavy emphase on therapeut1c group work. Family therapy 1s offered if the parents are a resource. V1lla operates a group houpe for aftercare. Average length of stay is $1-2$ years.

Referral Process:

Diecuse the referral with the CSD 11a1son worker. If the refarral is appropriate, aend a complete social sumary,using the attached outine, to the agency, wth a copy to the 11a1son worker.

12. Volunteers of Amer1ca:

538 S.E. Ash Street

Portland, Oregon 97214

235-8655

Emergency housing and counaeling for wothers and ch1ldren who are howelegs or in crisis. Funding 1s jointly through Children's Services Division and Public Welfare Division. Referrals may be by Public Helfare Division, Children's Services Division, or self-referral. by clients. Please telephone referrale directly to the facility. The CSD liaison person need only be involved if there are queations: or concerne about the placement.

Voluntears of America Shelter Evaluation Center 1s a separate program. Por referrals or information, call Judy Pretta.

13. Haverly Children's Home

3550 S.E. Woodward

Portland, Oregon 97202

234-7532 
Deceaber 10, 1975

Rage 11

\section{Populat ton Served:}

58 chlldren in three programs: tralnable mentally retarded, enotionally dleturbed, and shelcer care.

Trainable Mentally Retarded: 10 children, 8 or under, who function in the trainable range of recardation (50-55 I.Q. and below). Waverly provides 24-hour reeldential care for children who need to devalope self-help ak111. wuch as dreseing, feeding and tolleting and who are unable to live In the comonity.

Emotionelly Disturbed: 30 boye and g1rls, boys ages 4-12, g1ris ages 4-8. Common probleme at the time of referral include lying, otealing, bed wetting, diaruptive behavior in school and home, and zunaway, out of control for boye 9-12.

Shelter Care: Emergency housing and casework services for chlldren removed frow their own homes by law enforcenent. The lialson unit 1s not involved with the ahelter care component of Waverly's program.

\section{Inappropr lace Referrale:}

Trainable Mentally Retarded: I.Q. In educable range, non-ambulatory or eerlously phyeically dieabled child.

Esotionally Disturbed: Actively peychotic, ser lously asaaultive or. violent, history of arson.

School:

Waverly operates a residential achool on canpus and soes children also go out to public ochool dally.

\section{Program Componente:}

Trainable Mentally Retarded: Realdential care for children unable to live in the coumunity. Program focus is on teaching celf-help ok111. auch as tolleting, dressing and faeding.

Enotionally Disturbed: Children live in two unita, one coid and one boya' unit. Treatwent model io alleau therapy. Individual counceling 1s avallable. Avarage length of stay to 1 year to 2 years. Purchase of care monthly coet 1s $\$ 850.04$ per child.

Referral Process:

Discuse referral with CSD Llaleon parson. If refarral is appropriate; oead social aumary following outline actached. Send copy of referral to CSD 11aleon person. 
Decenber 10, 1975

Page 12

14. Salvation Arwy White Shield Howe

2640 H.W. Alexand ra

Porcland, Oregon 97210

226-4053

Population Served:

20 unwed mothers and 15 mothers and children. Maternity services are provided 1rregardless of age but residents in both programs tend to be 12-18. Pregnant women referred tend to need confidential maternity care, help in making decislons to keep or release their baby, and a atructured residential living situation. The Infant Maternal Progran for mothers and bables serves mothers who are Immature, need to develop parenting skills, are in a vocational or school program and have bables 0-36 months.

Inapproprlate Referrals:

Prenatal: Pregnant women who are psychot1c, have an I.Q. under 80 and are dangerously assaultive or violent.

Infant Maternal Program: Motherg who are psychot1c, have an I.Q: under 80 and are dangerously assaultive or violent; wothers who cannot tolerate group $11 v 1$ ing and who will not atcend school or vocat lonal training.

\section{School:}

There is a residential school on campus.

\section{Prostan Components:}

White Shield offers traditional residential waternity counseling and care. There is a hospltal and a school for pregnant women on caspus. The prenatal girls live on the top floor of the residential building; the mothers and children live on the bottom floor. The I.M.P. Program offers residential care for young or imature mothers who feel unable or unready to live in the coumunity with their infants. Mothers attend school or vocational training until they are economically ready to live on their own. A day care center on cempus serves children 0-3. Mothers recelve supervision and training in parenting skills a well as individual and group counseling. Average length of stay ia unt1l delivery in the prenatal program and 6 months in the I.M.P. Program.

\section{Referral Process:}

Discuse referral with CSD 1181son worker: If referral 18 appropriate, send a written referral to white Shield using the referral format ateched with a copy to the worker.' Please note that parents need to algn consent for placement and medical authorization for pregnant girls under 18 . 
Decenber 10, 1975

Page 13

15. Youth Adventures, Inc.

P.0. Box 770

Oregon C1ty, Oregon 97045

656-7081

Population Served:

G1rls' Program: 18 g1rle, 14-18, 14-17 ac time of referral.

Common behavioral problems at the time of referral include:

runsway, out of control, poor impulae control, school problems

lncluding truancy, minor delinquency, promisculty, drug or alcohol abuse.

Boys' Program: 12 boys, 14-18, 14-17 at time of referral. Comion behuvioral problemg at the time of referral are the same as for the glrla' progran except that adfudicated mafor delinquency, such as car theft, is more coumon.

\section{Inappropr 1ate Referrale:}

I.Q. under 85, actively paychot1c, dangerously asaaultive or violent, overtly homonexual, cannot be malntalned in public school; and adoleacents who are not motivated, cannot 1dentify personal probleas to work on, and will not contract to $g^{1 v e}$ up sex and druge. and alcohol.

\section{School:}

Ch1ldren wat attend h1gh achool, usually Oregon C1ty H1gh Sehool.

\section{Program Components:}

Youth Adventures operates a co-ed program with adolescents living In three girls' group homes and one boys' residence at the maln lodge on the Clackamas River. Youth Adventures ut1lizes a houseparant atefing model. Individual and group treatienty are offered. There 1s a heavy emphasio on traneactional analyalo and gestalt techniques. Individual contracts with adolescents ars used frequently and as adoleacents progress through the progran they way be asalgned junior counselor responsibilitles wth new residents. A group home in Milvauk1e 18 used for after care for 5 g1rls. Sose work with famplies 10 done but most adolescents at Youth Adventures are enancipated or go into alternate care rather than returning to their fanilies. Average length of stay 1s 1 to 2 years. Purchise of care wathly payent 1s $\$ 838.75$ per ch1ld.

\section{Referral Proceas:}

Discuss referral with the CSD 11a1son person to determine if Youth Adventures 1s the most appropriate placement. The llalion worker w11 then e1ther arrange an 1ntake staffing or place the 147 on the child care center walting list unt1l a vacancy occurs. Staffinge are held at Youth Adventures and atcended by Youth Adventures: staff nembers, the adolescent and h1s family, the referring caseworker and the CSD 11a1son worker. By the time of the Intake ataff ing, 
Decenber 10, 1975

Page 14

- cocial sumary neede to be sent to Youth Adventures vith a copy to the llaison worker.

16. Youth for Chriet

604 N.E. 20th Avenue

Portland, Oregon 97232

234-9776

\section{Population Served:}

C1rl.' Program: 9 g1rla, 12-18, 12-16 at age of referral. Comnon behavior probleme at time of referral include runaway, out of control, poor impulee control, school probleme including truancy, minor delinquency.

Boys' Program: 13 boye 11-18, 12-16 at time af referral. Common behavior probleme at time of referral are the same a for the g1rls' program except that adjudlcated ajor delinquency, such ap car cheft, 1. Eore conmon.

Youth for Chriet Shelter Evaluation Center to a marate progran. For referrals or Information, call Judy Fretca.

\section{Inapproprlate Referrals:}

I.Q. under 80, actively paychotic, dangerouely assaulcive or violeat, overtly homoexul, cannot be meintained in public achool.

School:

Muat be able to attend public achool. G1rle attend Corbett High School and boys actend Welchee Grade School or Sandy High School.

\section{Progran Conponente:}

Youth for Chriat operates two child care centers: one for girla, near Corbett; one for boys, on the Salmon River at Weme. Both programe ut1lize a comblnation live-1n houseparent and ohlft coverage wodel. Individual and group treacments are of fered. Boch programe have a eysten of 1ncreasing privileges and responsibility by levels. Both work with familles when parents are a resource. Average length of etay 1s 9-12 wonths. Purchase of care wonchly cost $10 \$ 743.29$ per child.

\section{Reforral Procese:}

Diecues referral with the CSD lialson person to deternine if Youth for Chriet 1s the mot appropriate placement. The 11aison worker vill then either arrange an intake staffing or place the 147 on the child care center walting liat unt1l a vacancy occurs. Child care center staffing are uaually held at the Resource Branch and attended by Youth for Christ ataff, the child, the referring caseworker, and the liaison worker. By the time of the 1ntaka staffing, a social sumary needs to be sent to the Youth for Christ, with a copy to the lintson worker. 
APPENDIX B

SUBCONTRACTING FOR TITLE XIX PAYMENTS

THROUGH THE MENTAL HEALTH DIVISION 


\section{MENTAL HEALTH DIVISION}

MTMOLANDUM

TO.

FROM:

SUDECT:
DATE Novamber 25, 1975

mantey Mental Health Prograne

Subcontract Agencies.

Pat Krieger $\mathrm{l}^{\prime}$. -

Hedicald Consultant

Subcontracting for T1tle XIX Paymenta

Attached are the completed guidelines for implementation of IItle XIX in a subcontract agency. The need for this kind of Information cane out of our Septeber TItle XIX workehop.

1t 1s Important to remember thet these are only guldelines and not rules. The process way work somewhet differently In your county, and for this reason you nay vant to anke some modif 1cations.

If you have any questions, please teel free to call we at 378-2161.

tom

Attachent 


\section{COARUAITY PROGRM RESPOHSIBILITIES}

1. Datermine 18 proposed progran aeete identifled need in the councy plan.

1I. Detenine whether progran 10 duplicetion of eervices exiecing vithin the Comantey Mentel bealth Progran.

A. Does 1t eerve a diflerant populetion?

B. Io It neaded is a different geographic area?

III. Detarnine if the proposed progras adde to comprehenalve eental bealch oyere.
A. Io 1t a needed nav sarvice?
1. Doee 1t neet a population need not eerved?
C. Does $1 \mathrm{t}$ have a high ut1lisation by a terget populactoo?

IV. Request T1Elo XIX inforantion booklet froe Hedicald office if you do not elready have one. 378-2161

v. Look at the propoeed progran budget and f1ecel dealgn to detarnine $1 f$ :

A. Locel atch money ( 40.967 of blllinge) 10 avallable. Hnteh money 10. defined a local or state dollers used to clets Pederal financial participation in the coer of providing eervicen co eligible Helfare reclpiente. If Pederal dollars, auch se revenue ahnering or CETA funds, go through the county, they wy be conetdered local funde. (See Ors 430.655) The mateh money 10 cosetines called "front noney" and 1s eent beck to Public Welfare, who uses it to clate the Pederal dollars.

B. The proposed progran bae the capec1ty to:

1. Keep necenasy eccountlog of ell funds.

2. Do neceisery billing.

C. The Comunity Mencal Beelth Progran will be Eaking a financial concribution to the progran through grant-in-ald. 
Comentity Progran Reoponeibllitien

Rage 2

D. The fundlos aechaniene for Title XIX are clearly uoderotood.

1. It thare are no mental healtb etate dollers in the progran, the subcontractor keope the 59.048 of the b1llinge and 1 a responetble for anding in the front wopy each wonth.

2. If there 10 a grant-in-ald contribution, you need to know whet perceat $1 \mathrm{t}$ 10 to the proposed progran's cotal budget. Thet percentege vill be deducted tron the $59.04 x$ Pederal chare. The secharien uned 10 for the Mentel theleh Diviolon to deduct the mount Iron grant-in-aid, and therefore you'11 heve to deduct froe monthly payente to the subcontiactor, or blll for the mount on a watbly basla.

vt. Une Title XIX 1nfornation packet fron kadicald Office and deternine 12 the propoeed progran:
A. Is operationally sound - capable manegenent eyetea.

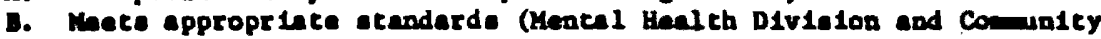 Mantal Bealth Progran).
C. Cap neet IItle IIX requireante a outilned in tha Adninietrative nule and Mental Benlth Divioton-Public Welf are egrecaent.

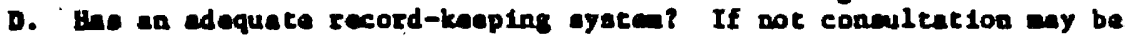 provided in thie aren by Medicald offlce and Kantal Health Diviaton staff.

VII. If progras neete above criter1a, a contract and ut1lization review plan ahould be developed. A nodel 1a avallable in the Madien1d booklet.

VIII. Iring in the Kadicald Office and Comuntty Mentel Health Specialiot for coneulention an necded.

IX. Anand county plan and faclude propoead progran in unbelle coneract.

x. Contrect, elgned by county and subcontractor, should be eubatted to the eppropriate Commalty Specialiet, wo wll eceure epproval fron epproprinte Aegletant Aduiniatrator. 
Cominnity Peogran Reoponelbilleles

Paye 3

XI. Once contract 10 approved and atanderdo ere aet, you any aek your

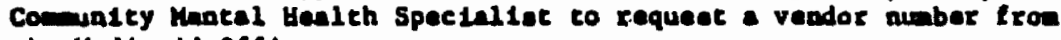
the Hediceld 0efice.

XII. Supply epplicet1on for "letter of approval" according to Mdntnistrative Dule 12.010 .

xIII. Monttor contract with ongolng congultation frod Kantel tanth Diviolon Raglanel office and radicald office as needed and requented.

XIV. The Medicetd office an be used as linicon with Public Welfere to halp

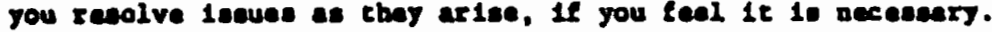




\section{RESPOUSLBILITIES OP SUBCOMRRATORS}

I. Survey cllent population for Welfare ellgibles or pocential eligibles. Look te Helfare case number. Programs 1, 2, 3, 4, 65, 82, and 92, are cone of the prograne ellgtble. Only progras 5 le not ellgible. If you have cliente on SSI or whoee ellgibility is unclear, please refer then co your locel Welfere offlce tor deternination. If your aurvay showe a elgaiflcant auber of aligible clience ...

II. Telephone Tric1a Mortell, Mediceld office, 378-2161, requeating T1tle XIX Inforantion packet.

III. Contact your Cominity Mentel Health Progren DIrector to see if abcontractiog 1o a poselbility.

IV. Once the I1tle XIX Information pecket is recelved, deterneloe 16 requirenente can be met.

A. Mdniniotrative Rule

1. If you plan to blll for a eocialization progran, does your progran met the defin1tion?

2. Tire and halth codee cen be net?

3. Hedical preecription or nedical supervielon? (See page 6 of the Adalnietrative Rule)

B. Mental Health Diviolon - Public Welfare Division Agrement

1. Does your progran nov provide a envice outlined in the egreement, or can it provide such a service by waking olight progras Iaprovenente?

C. Tunding Relationships

1. If there 1t no mencal health Btate dollar participetion, you aeed 40.967 atch money (local money) to be used to clain the Federal flnancial particlpation. A monthly check for 40.967 of the billings, must be cent lato the Mental Hesth Division. CEIs or revenue sharing funde asy be considered antch, if they so through the county oyeten. 
Reaponetblittee of Subcontractora

Page 2

2. If the Mental Health DIvialon is finnacially contributing, we wat recover state percent of the tocal progras coste tron the Foderal ehare. Wo do this by deducting eron county grant-10atd payment.

3. A eliding fee echedule, for non-Title XIX patients, auet be developed. You ay dot b1ll Public Welfare sore than you would blll a private patione, however, you any develop a ellding tee schadule beaed on client's incone.

4. The I1te XIX fee echedule for b1lling Walfare 1o a pare of the Informetion packet. Tou vill noed to use th1e to ent1mete your I1tle XIX Incone a wil a for billing.

D. Io the service you wheh to b111 undicald for already identifled in another contract you any have wich CSD, VDD? You mey not b1ll two sicactes for the cane sarvice to the vene client.

8. Is local ench money ava1loblet Io 1 t clearly identifled?

v. Contact Commitey Kantal Bealth Progran D1rector. He neade:
4. Aseurance that your progran providea noeded enrvice to Identelfied population.
D. Budget.
C. Trogtan deecription.
D. Neurance Medicaid rules can be met.
i. Derractve upplenent to county plap.

vI. Oace Coemuntty Mantal Health Progran Director hae agreed on your progras, be my:

A. Aring In a Comanity Mental tealth Spacialiet and the Medicald Office to halp in:

1. Contrace developaent - aee exampla In Medicald booklet. The contract anede to be algen by county and Subcontractor.

2. Record-keeping eyotea developmeat.

a. Coatect obect to provide documentation of cervice for bulling. 
Responatb111c1es of Subcontractors Pere 3

b. Treatenent plan.

1. Conle

2. Progrese cowarda neeting gonle

c. See problea-orlented record enples, In Madicald booklet, (chese are only exceples, you any develop your own torms 12 you us (sh).

3. Developent of a utilizection rovieu plan. Sead a copy to the Hedicald office.

VII. Requeat "letter of approval" froe Mentel Health Divlalon, eccording to Med Mdnialetrative Rule 12.010. D1acues vith your Comunity Eeatel Health Rrogran DLrector.

VIII. Whan contract has been algaed and approved by the Diviaton, (Reglonal

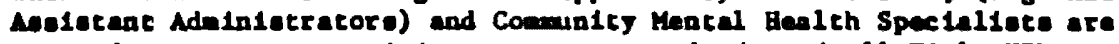
aseured progran aece ninimu progran acandarde and all Tielo XIX requireante, vendor number will be requented. The procese 10 through the epproprlate Conunity Mancal Healeh Speciallet to the Hadicald offlee, who in turn requeste the nubar froe Public Nelfere.

Ix. Once your vendor number has been received, requent s01-A b1lling fortes froe your locel Public Welfare branch office. Ticle Hortell 10 avallable for consultation on b11110is. (378-2161)

$x$. Sand billing forae directy to Rublic Welfare state offlee for paynat.

Rublic Welfare Divialon

Fiecal Sect100

Public Service Bullding.

Sale, Oregon 97310 


\section{Reoponolbllitied of Subcontractors}

Page 4

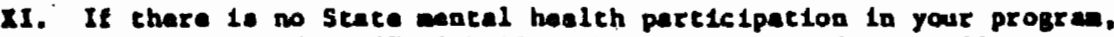
eand a check (40.96\% of blllinge), and a copy of the billinge to:

Donalee Mulr

Adalalatrat lve Servicen

Mantal Health Diviolon

2570 Center Street, dE

sale. Oregon 97310

If the Stete 1s aktng Elnanciel contribution, 40.962 mech money plue a percentage of Pederal share equel to Stete's participation In your cotal progran will be deducted from your grant-10-ald or

"alternetives" funde. Deteratine this deduction so you vill be cortain of the asount of Federal dollare recovered for every blllias.

XII. You are reaponelbla to the Comminty Mental Haalth Progran Director who wll conleor and provide oupervielon for your progren.

XIII. You need to work out eny flanciel arrangenente with the Camatity Macel Hasth Progran. If there are state ental bealth dollara In your progran, he'11 need to deduce fron your monchly check, or to collect through billing.

XIV. You any expect a alte vialt re: your requent for a "lacter of approval" tron the Mentel Halch DIvialon. Appropriate notification of tino of alte vielt vill be arranged. 


\section{IESPONSIBILITIES OF RECIOHAL OPFICE}

I. Diecues proposed neu progran with Mental teeltb Divielon Progran offlee to lneure it aeete minlaum eteaderde sec forth by the Division.

II. Has te bean ande a part of the county plan?

III. Help in budget developaent as naeded.

IV. Provide help in coatract development en needed.

V. At request of Comminty Mental Health Progran D1rector, act a lialwon between Subcontract, Comantty Progran, and the Mentel Balth DIviolon.

VI. Secure IItle XIX consultation as needed.

VII. Make eure all I1tle XIX requiremants are net.

VIII. Is budget proper, and 1s metch money elearly Identified?

IX. Secure contrace approvel from Reglonal Mesiatanc Adnintecrator.

$x$. Recelve request for "letter of approvel" for service eleaent; arrange with Progran office to coaply with Adatatetrative Rule 12.010 . 
Reopontibilitiee of Regloal office

Page 2

X1. Once contract 1o olgaed and all T1Ele XIX requireente have been ant, : requent Hedicald office (In wictag) to alk PLD for a veador auber.

XII. Provide o0golag eupport, cake part in ut111zetlon rev lew ae needed. 


\section{LESPOUSIBILITIES OF MEDICAID OFTICE}

t. Keep Reglonal and Progran offlces Informed of concacts vith Comunity Prograne and potential subcontractore

11. Provide Informationel materials to Subcontractors and Comuatey Programe on request.

III. Provide conoultation as aeeded in following areas:
A. Dudget-fund Ing relat lonahlp
B. Utilization reviaw
C. Record-keep ing
D. Title XIX requiremats
E. Blllas tnetructiona
7. Contract Information

IV. Make eure all conditione of Adminletrative Rule and Mental Health Divialó - Public Walfare Diviolon requirance have been net.

v. Once Comminity Mental Health Speclallet has informed Medicald office thet all requiremente have been ant and the contract has been approved by the Division, the Medicald OfElce vill send aco to the stece Public Melfare Diviolon requesting 1sounace of a vendor number.

VI. Do an onste vielt, after notifylng and working with Comuntty Mental Health Progras D1rector, Comeunity Mental Health Specialiot, and agency regarding time of onolte.

VII. Monitor b1llinge.

VII1. Keep utilization revied plan on file. Continue conoulcation on weilizacion reviev and records. 
Responsibilitied of Medicald Office

Page 2

IX. Supply MHD, Businese Serviced, with nacienenry financiel Information regardlas vendor numbers and percentege of recovery.

X. Provide ongolng support and relay any new laforencion on I1Ele XIX to omualty rograna and ubconeractors.

XI. Llateon to Public Welfare Division regardiog inauen relative to the eubconcracting procese or billing problems. 


\section{PROGRUY OFFICE RESPONSIBILITIES}

I. Set elninu progran ecandarde.

II. Eetabliah evaluetion and revieu procedures.

III. May cake part in Inteinl developant of prograne.

IV. Recelve and ace on application for "letter of approval" for earvice eleaent. Conply with Adnlatetracive Rule 12.010 regarding onole vielt raport and lesunce of letcer. 
APPENDIX C

PROPOSED DAY TREATMENT PROGRAM

FOR CLACKAMAS COUNTY 
PROPOSED OAY TREATMENT PROGRAM FOR ADOLESCENTS

The following is a proposal for an adolescent dey treatment program for residents of Clackamas County. This program would be administared inrough the Clackames County Mental Health Clinic in full cooperation with, and with staff participation from the following Clackamas County Human Resources ogonciess Children's Services Division, The Intermediate Education District, The Juvenile Court and Parrote Craok Boy's Ranch: 
Soction I PROĢRAM OVERVIEN

Gne of the major ressons for consideration at this tian of a Day

Treatnent Program for tho adolescent is an awạroness of the lack of rasources providing the intensfty of service needed. Existing prograns aro designed to provide sorvice for youngsters who noed residential trosiment or for tinose who can respond to Ereatiant in a traditional outpationt sotting of a less intensive and extersive nature. There is an absence of resourcas for a lapge population of adolescents for whom axisetng programs are inadequate and who could respond to a progran which is designad to bridge the gap between outpatient and residential care.

The purpose of a Day Traatinent Program would be to rasch the adoiescen: and his family as early as possible before the labeling process has occurrad and prior to involvement with the Juvenile Court, suspension fron sechooi or serious deterioration of the ramily situation. It is anticipased that this progran would be a community-based and cominnity-supported resource with stafis and support coming from ail agencies within the human resources network in Clackaras County. Primary overall goal of this program would be to al ter dysfunctional behavior patterns in both the child and fanily in such a way to allow them to return to the comsunity with tools and resources to function without the intensive support of the progran. Supportive followup services mould be offered by the agencies in the community..

\section{Target population}

The primary target population for this project would be adolescents (age $14-18$, both sexes) with a high probability for residential placoment or for serious delinquent bahavior without intensive therapeutic interven- 
tion. In eddition, this program would be open to those youngsters in e transitional phase, returning to the comunity from residential programs, such os Damosch Stote Hospitel, Parrott Creek Boy's. Rench, Youth Adventures, etc. Two groups not approprlate for this progran would be the activily psychotic youngster and/or the truly drug addicted youngster. This would not screen out drug uears or youngsters whose problens include drug abuse.

Referrals to this type of program would come primarily from the Public Schools, but 1 lso from such agencies as Children's Services Division, Juventle Court, Mental Health Clinic and the Public Schools as well as the numerous restdentiel programs in the area. Reforrals are al so anticipated from such sources as winisters in the commity and Individual familles themselves. Spectal priority wil be given to edolescents from larger fanilies with younger siblings who are in the olementery schools.

Treotment pht losophy

The program is designed to include $10-12$ adolescents and their fantlies for - perfod of three months. (This epproach would allow 40 - 48 edolescents and their fantites to be served each year.) The rationale for this approsch cones from reseerch findings which show that an intensive progran of shorter length has more impact than a long-term, lass intensive treatmant program. Research 1 so demonstrates that the most significant changes in fantly pattarns oceur during the initiel period of counseling.

As a community we ore combitied to a philosophy of norking with femilies. He belleve the fanily unft is the key to individual growth and nurturance. The mitiple impact epproach proposed here has been shown to be effective in working with the fantly, who has an adolescent who has been excluded from the comunity, or whose exctustion is imoinent. While this progrem has a variety of treatnent opproaches; they ore unified in their adherence to the growth model.

"The growth model is based on the notions that people's behevior 
changes through process and that the process is represented

by transections with other people. Illness is belleved to

be en eppropriete communfative response to a dysfunctionat

systea or context. It is therefore belfeved that IIIness

goes awey when the Indtridual is removed from the moladep-

tive system or the system is changed to permit heal thy

responses and communteation. Growth oceurs when the system

permits it."

Our commitment is to a multi-faceted approach designed to impect on the feally to promete growth in the individuais and to moke changes in the faeily to promote growth in the individuels and to make changes in the fanily system which will allow the fanily to serve its murturing role. In keeping with this philosophy, emphas is will be pleced on trestmont ot adolescents from families with younger siblings. This intervention would provide strong preventative component, es wll as an amel forative component.

Cols and objectives

Coals for this progran may be stated in three major areass overall goels for the projects goals for the individual youngster in the progran, and gosls for the fently.

A mejor project goal may be stated in terms of reduction of inappropriate referrals and plecements in residential and other treotment progras in the comminity. The screening aspect of this progran would result in eppropriate referrals and o more officient use of extsting communty resources. A second gool would be to provide followup consultation for the adolescent family in the communtty resouree providing service to the family. This consultetion would Insure contimution of the growth process begun during involvement with the program. A third goal would be to provide a transitfonal resource to the community for those odolescents leaving residential care. A fourth important gool of this project is to contime the interegency cooperation and involvement in identifying contwity needs and working toword officient utilization of communtty resources. 
There are three primary goals for the adolescent involved in the progrem. The flrst, - significant reduction in antisocial behavior which would alter the Individual's Identity to an Identity which has legitimacy within the community. second, an-improvement in social adjustment as roflected in paer and Pantly relationships. Third, an tmprovement in self-image as measured by discrepency scores on scales of personel adjustment.

Cosls for the fantly would include a development of problem-solving techniques to be used within the family structures laproved commenication between. pemily members; greater parentel understending of adolescent behevior: and a better fantly self-image through improved self-image of all fanily members. A releted goal would be one of prevention of similar problems experienced by the Identified adolescent from developing with younger siblings In the fanily. 


\section{Section II PROCRAM DESCRIPTION ANO IMPLEMENTATION}

The Day Treatment Progran would consf st of two basic commitumess 1. progren designed specifically. to facilitate the developrant of are functional behevior pattern in the adolescent and 2. atrong emphasis on therapoutic intervention with the fenily. screaning and evaluation for admisston

The screening procedures following referral would include obtaining a social history and a psychological summary of each child. The soctai history should Include the complete summary of family interactions, Identifying significant femily nembers and their prosent relationships to the youngntar. School progress and behavior would be appraised. This would include information from the referping school, in cooperation with the IEO. This would insure that the educetional component of the program would be mat for the edolescent and the sehool

The edolescent's prianary fantly (own or foster fanfly) must be willing to have intensive involvement with the program and be amendable to change in the fanily structure. Upon roferpal, the case will be peviewed by an Impact tean composed of staff from the Day Treatiment Program, a representative from the reforing school, and from agenclas within the commity. This will include an intensive interview with the farlily for the purpose of evaluation and planning. Following this the case would be staffed with recomendations being provided for the intervention with the adolescent and his famtly. Recommendations wight include reforral to the Dey Treatment Program, raforral to other existing communtty resources, a raferral to a residential progran, whtchever might be deemed more appropplate by the screenIng stapf.

\section{Program components}

As a result of screening and evaluation, one or more of the components of the direct treatment program and the educational and vocational progran will be included in the individual plan designed for each adolescent and his 
fanliy.

A. Diroct ereacment

The adolescent progras will include insensive group experience and may include individusl counsaling sessions, as indicated. The educationai ard voseifonal aspects of the progran will fnvoive an individually dusigned canbination of the following:

1) attonding a local high school

2) ani-course program

3) tutorial program - students texching studonts

4) adolescents teaching in local grade schools

5) comsunity coliege involvament

6) neighisorhood youth corps.

In addition to the treatment plar cieveloped for the adolescent there wou: 0 so a variety of treatment nodalitios available for the parents and family, most of which would be conducted during evening houps to facllitate full participation of all appropriato family manbers. These would inelude Family counseling, Parent's Groups, Parenting classas and Marital Counseling.

The Fantly Counseling, Parents Groups and Marital Counseling would be stirifod by mertisars of the cooperating agancios and would inciuda at least ona menjer of the individual imily's impact tesm. The Parenting class would bo Eaught by a mernier of the Mental health Clinic who has had past experienco in teeching sucin ciasses and would je ained at broadening parents' uncerstanding of adolescent behavior and seaching effective techniques for dealing with soth desirable and undesirabio behavior.

3. Educational - Vocational activity

Cooperation and coordination with local public school's is considered essential to the educational-vocational activities of this project. Clackants Sounky IEO hes agreed to coordinato she comaunfeations with cooperating schools 
In arranging cradits, curpleulum, tutors and other activities utilizing school facifities or stapf nembers. A school consultant will be a manbar of the staff and will be evoliable for consultation with the raferping school. Credits will be offered for acedenic eccomplismonts particularly in the skflls areas of reading, wath, English, history. Courses necessitating equipient, tools or materials wtll be arranged through the public schools. students will acquire eredits for social and personal developant and communtcation skills besed on their Intensive involvement in group, Individual and peer counsoling sessions. Credtes will ol so be ovallable for afforts in cereer development or training. Plecements will be sought in part or full time jobs and In vocettonal courses in public schools and the communtty college. Communtty cooperation will be sought for training plecements sufficiently diverse to proFde growth experiences for all students.

Under the supervision of one teacher who is extremaly proffelent in interparsonal comminication and counseling, the concept and techniques of "ichtidran teaching children" will be fundemental to the educational program. It has been found that learning takes, place at a meh accel arated rate when students are involved In the teaching process. While tutors learn and retein the anterial more rapidiy, and completely, the students al wo learn more ropldly when taught by peers rather then "adult" teachers. While this concept is used by som schools on a 1 iafted basls, and usually reserved for "good" students, It is completely practicable es a Pundamental educetlonal philosophy. Benefits range Par beyond staple skfll bulfing Into role exploration, communication and interpersonal relationships, and self-concepts and worth. Students from the profect and from the publ ic schools will be offered eredits and/or salarles for tutoring time.

On first entering the progren, each person will detormine the subfect ereas In which he is defictent and needs remediation, as wall as areas of Interast and motivation. When needed, standardized tests ore ovallable through Cleckenas County IED. Intefel educettonal offorts will be to bring the 
deficfent areas up to a survival level, after which individual intereses will determine curpiculum.

Initial contects with local school district administrators and counse: Ing departments have indicated strong support, particularly in that most schools have been frustrated in serving, oven in coping with, the population identified in this project. While direct referrals will initially be quite Ifmtted in number, project results and effects, expertise and consultetion will be welcomed by public school parsonnel. Communication and Interection between schools and human resource egencies can definftely benefft by the processes Involved in this profect.

\section{Evaluation}

A. The individuel and fantlyz

At the end of the three month involvement In the Adolescent Day Treatmant Program an evaluation of progress will be made and recommendations concernting the followup program. Optlonal recommendations might include continued involvement In the Day Treatment Profram, referral to a community resource, or termination / foll fowup by the Day Preatment consultation staff. It 1s possfble that a recommendation for restdential care might follow a perfod of time In the Day Treatment Program. Criterle for ovaluation will be relevant to the Individual and may differ with each individual. In dealing with adolescent and femfly with critfcal adjustment problens, it is impossible to sat a speciffe standard as a success criterio. Movement toward more positive attitudes and behaviors within the fartly and within the communtey will be the enticipated direction and can be messured progressively as the program is carplad out. Followup procedures after the famfly is terminated from the program will be made and success of program will be measured to some degree 
by the stability of the changes which occur.

B. The program

Evaluation of the progran is regarded as essential in order to find areas of success and areas on which the program could be improved. Therefore, in addition to a valuation recomendation concerning the adolescent and his family, an evaluation of the progran itself will occur at the and of each three month period. This will be accomplished by allowing for a two week break between the three month term before esch group is begun. The progran eveluation will be conducted by an outside organization (such as the Teaching Research Program at OCE) contracted for this purpose.

\section{Stafing}

The Adolescent Doy Treatment Progran staff would be comprised of the school consultent. following positionss ofrector, Counselop-Teacher, Counselod, a commity organization worker for volunteer coordination and lialson with the loy communfty, a graduate student in field placement, undergraduate students and wolunteers and secretary. The agencies involved in the project would iso make staff members avellable for the famtly therapy, parents' groups and marttal therapy.

The diractor and counselor would be montal health professionals, such as a psychiatric social worker or a clinfcal psychologist with extensive training and experience in working both with groups and with adolescents. The CounsenlorTeecher would be a cartified teacher with special proficiency in communfation skills and interpersonol behavior. Experfence in counseling adolescents would be required. The director, counselor and counselor-teacher would be responsible for the functioning of the program as well as the supervision and training of the remaining staff. A more detailed outline of proposed staff may be found in the section dealing with the budget. 
Posteton

ofrector

Counselor

Counsel or -Teacher

Commint ty orgenization

Worker

$662 \times 6,695 \times 6$

Clerk/stenographer

sehool Consultent

Payroll Costs

$20 \%$

Iten

Psychological Consultotion

Paychiatric Consultation

Rent and Utilfties

Tel ephone

$1192 \times 6,1252 \times 6$

$045 \times 6,888 \times 6$

$845 \times 6,888 \times 6$

$5 \times 492 \times 6,5 \times 517 \times 6$

$845 \times 6,898 \times 6$

Jenitorial Service

Transportation

Inservice troining

Equipentent and Supplites

Food

Rosearch and Evaluation

\section{Annuel Salery}

14,664

10,398

10.398

8,142

3,027

10,398

37,027

$11,405.40$

\section{Anmul Cost}

2,500

2,500

3.600

240

480

$1.500 \mathrm{~s}$

750

300

3,000

3,000

17.870

57,027

$11,405.40$

TOTAL 
In' Kind Services Provided by Coopereting Agencies (Based on en ennual solary of (15,000)

1. Therapists - parents groups ( 8 hours per week)

3,000

2. Parenting class ( 2 hours por week)

3. Merital Therapy ( 4 hours per week)

1.500

4. Impact team (Equivalent of 1 full time staff)

15.000

5. Superviwors - Students and volunteers (4 hours waek)

1,500

6." Planning and coordination (2 hours par woak)

In addition:

Qffice space.

office equipment and supplifes.

Supplemental secretarial help.

Inservice training.

To be provided by coopereting agencles. An actual cost estimate is impossibia to deterinino at this time. 
STATISTICS

Table I

Shel ter Care - Clackamas County C.S.O.

\begin{tabular}{|l|l|}
\hline YEAR & $\begin{array}{l}\text { Number of Children in } \\
\text { Shel ter Cäre }\end{array}$ \\
\hline 1970 & 118 \\
\hline 1971 & 181 \\
\hline 1972 & 243 \\
\hline $\begin{array}{l}\text { Jan. } \\
1273\end{array}$ & 237 \\
\hline
\end{tabular}

a) Average langth of etay in shelter care (1973) 10.7 days.

b) $73 \%$ of youngsters remsining in shelter care over 7 days.

ware in the 13 - 18 year old age range (1973).

c) $77 \%$ of youngsters in sheltor care ware in the 13 - 18 year old range (1973).

Table II Foster care - Clackanas County C.S.D.

\begin{tabular}{|c|c|c|c|}
\hline Month & CSO Payment & No CSO Payment & Institutions \\
\hline July 172 & 204 & 4 & 57 \\
\hline Aug 172 & 289 & 3 & 73 \\
\hline Sept. 172 & 333 & 9 & 66 \\
\hline oct. 172 & 322 & 2 & 68 \\
\hline Nov. 172 & 421 & 12 & 76 \\
\hline Dec. 172 & 420 & 17 & 75 \\
\hline Jan. 173 & 408 & 11 & 79 \\
\hline Feb. 173 & 321 & 12 & 93 \\
\hline Mar. 173 & 391 & 32 & 104 \\
\hline Apr. 173 & 391 & 13 & 115 \\
\hline May 173 & 364 & 30 & 97 \\
\hline June 173 & 338 & 18 & 29 \\
\hline TOTAL & 4342 & 175 & 1002 \\
\hline
\end{tabular}


There were $144_{4}$ naw adolescent $\left(13^{\circ}-18\right)$ cases opened at the ciackamis County

Mental Kealth Cifnic during the perlod between July 1,1972 and June 30, 1973 
P.DOLESCENC DAY RAEATHEHT FLOU CIMRT

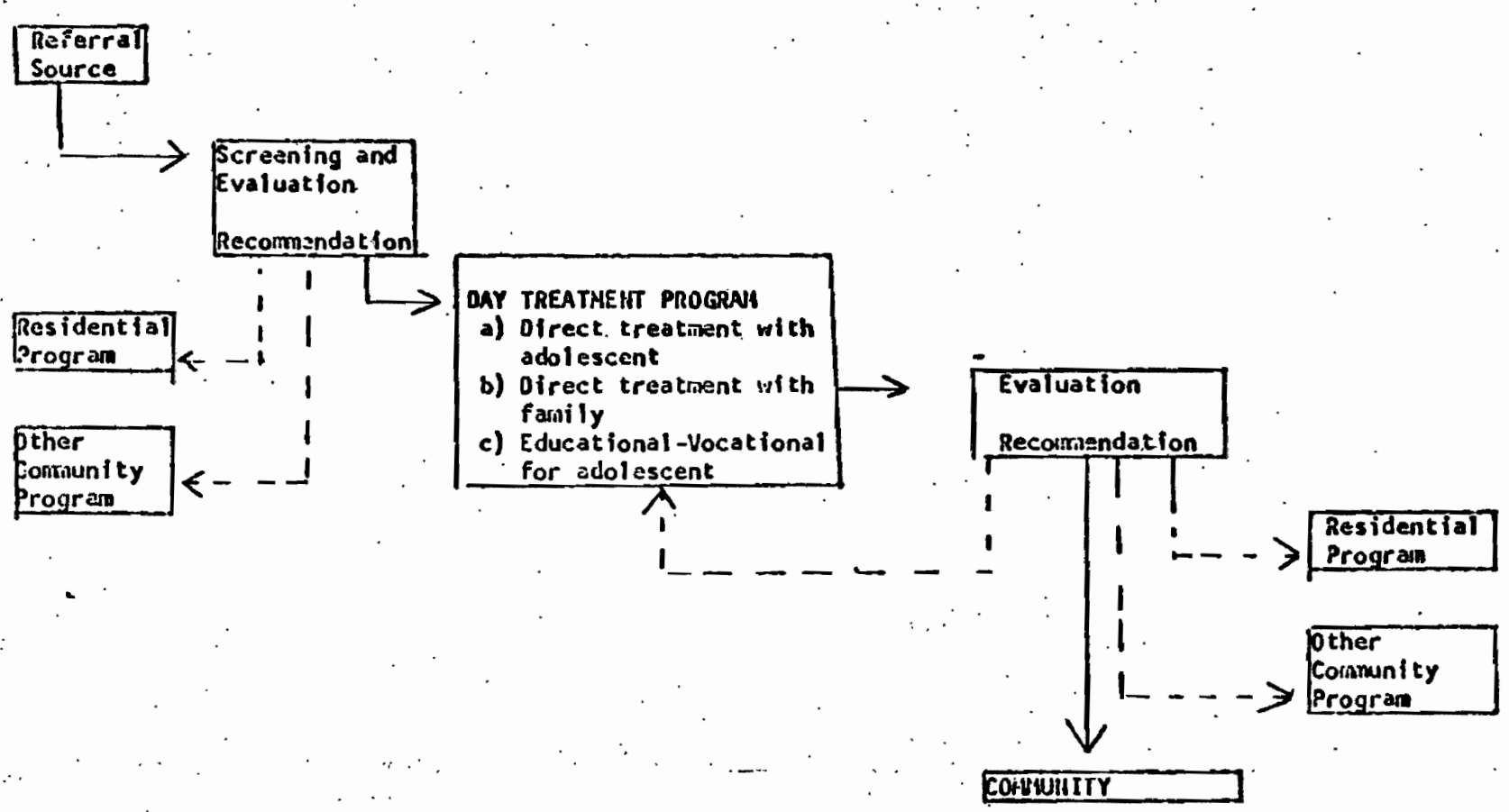


SOUACES OF IHPUT FOR ADCLESCEIIT MAY TREAT,AEIIT PROGRAH

PROGRAH COLIPONEMTS

1. otREct tREATHENT

2. EDUCAT IOHAL - VOCA TIOML

3. "SIG BRO THER"

4. screentig avio evaluntion

5. Training

6. PROGRAN DEVELOPHENT AHO EVALUATION.

\section{SOURCES OF IHPUT}

SOURCE

Mental Health Clinte

PROGRAN COHPONENTS

Childrens Services Diviston

$1,4,5$ and 6

I.E.D.

Schools

Juvenlle Court

Parrott Creek

$1,4,5$ and 6

2, 5 and 6

1. 4 and 6

$1,4,5$ and 6

P.S.U. Graduate and

Undergraduate

Students

1. 2 and 3

Volunteers

1,2 and 3

The Adolescent Day Treatment Frogran Staff wfil be responsible for coordinating and 6 components and be directly involved with thair faplementation. 


\section{TRAINING}

It is anticlpatod that the proposed pregran will provide a vehicle which graduate seudents from the school of social work and counseling psycho:ogy Departmont at Portland State could receive practicum experfence. Such students would be required to spand 3 terms, at laast 2 days a week, in the program. This would assure some continuity of staffing during the time the adolascents were in the program. Undergraduace students, upper division leval In bahavior sciences could $\$ 1$ so be involved in a componion "big brother" progran with some of the adolescents, as indicated by need. This would give the program a dual role, both providing direct services to emotionally disturbed youngsters and their families and supplying some much noeded practifun experience for students.

others involved in the training would include staff members fron various comunity agencies. Paraprofessionals and a volunteer progran would serve as. an adjunct staff to the progran and would be trained in this capacity..

\section{Appendix $F \quad$ FACILITY}

A factitty proposed for housing the program would be a bullding known as the Annex. This is owned by local church and is rented to the Mental Health Ciinic at the present time 2 days a week and houses the adult day treatment program. The building is a fairly large, comfortsble house providing rooms of varfous sizes appropriato for both group and individual counseling and for the ectivitios of the program. There is also a kitchen which would allow for serving a noon mal. It is anticipated that this facility would be available on a rental besis as it now is for the adult progran.

Opfice space for the Adolescent Day Treatment Program Staff will be provided by the Mental Health Clinic and/or other cooperating agencies. 


\section{TYPICAL CASE HISTORY WITH DAILY DAY TREATMENT PROGRAM SCHEDULE}

CASE hisTORY, M. N. Male

Birth Dates 6-26-58

M. Pirst came to the attention of the Mentel Health Clinic on September of 1965. The presenting problem at this time was a reaction to the deoth of his father who diod during the surmer of 1965. Both M. and hls mother were seen at that time and no further contact was made with the Clinic until May 1972. At this time M. was 14 years old and a freshman in high school. The presenting problem at this time was some difficulty M. was experiencing in sleeping and subsequently some behavioral difficulties at school. He and his mother ware not getting along well and he was resisting her attempts to discipline and control him. A psychological evaluation wes done at that time and a recommended treatment program involved group therapy for M., Individual therapy for his mother with occastonal sessions with the two of then being seen together.

This program was undertaken with somewhat debatable success. Following this, M. became involved in some minor dolinquent behavior which involved the Juvenile Court, the situation with his mother deteriorated and he, at her request was removed from the home and was in foster care for several manths. He went through thrae foster hares during that perlod of time. and did not make a successful edjustment in. eny of them.

M. manifested some symptoms of depression and wes hospltallzed at Dammesch Hospital for approximately one month for evaluation. During this time he made some improvemant and upon a discharge was once again referred to the clinic and has been involved In a group therapy program here.

During the perfod of time that M. has been Involved at the Cilnic he has not been in school, which means that at this point he is facing ontering school once again as - Preshman. He is expressing a great deal of apprehension about getting back in sehool and the present plans include enrolling him in a high sehool which he has not previously attended.

Had the Day Treatment Progran been in existence last year M. would have been an excellent candidate for such a program. It is entirely posstble that should his school adjustment not be satisfactory that such a progran would again be feastble for $M$. during the coming year.

Monday:

$$
\begin{aligned}
& \text { 9:00 - 9:30 a.m. M. arrives and mixes with others. } \\
& 9830=12,00 \quad \text { M. attends Adolescent Group. } \\
& 12800-1800 \quad \text { Lunch } \\
& 1800-1830 \text { Unstructured time. } \\
& 1830 \text { - 2\$30 M. attends class at local high school. (music class) } \\
& \text { 3:00 - 4800 M. Is tutored in reading and math skills at the Canter. } \\
& \text { 4:00 Progran ends. M. returns hom. } \\
& \text { 7800 - 9800 Mrs. M. sttends parent's group. }
\end{aligned}
$$


TYPICAL CASE MISTORY WITH OAILY DAY TREATHENT PROGRAM SCHEDULE

Tuesdeys 7:30 - 9,30 p.m. Mrs. M. eteends parenting class.

7830 - 10800 p.e.. M. spends ovening with "big brother".

Hednesdays 9,00 - 4800 M. repeets Nonday's schedule.

Thursdayi 7830 - 9:30 p.m. Pantly counsalling - M. and his mother, Mrs. M. occastonally signiffcant others in the extended fantly constellation might be included in the counseling sessions.

Fridoy: $\quad 9,00-1,00$

M. repeats Monday's schedule.

$1,30-3,00$

M. eutors a grade school youngster in math."

$3830-4,30$

M. anets with his Juventle Court counselor, "big brother" and stapp person to review the activities of the past week and to plan for a coning week of activities. 
APPENDIX D

A GROUP HOME/HOSPITAL TREATMENT MODEL

FOR DISTURBED ADOLESCENTS 


\title{
A Group Home-Hospital Treatment Model for Severely Disturbed Adolescents
}

\author{
LIID.T R. HOHFMIIN

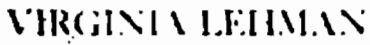 \\ E.I.1 D. $\% F$.
}

For severcly disturbed adolescents who are ready for discharge from hospitals but are expericncing long delays in placement elsewhere, a community-based group homc operating in cooperation with a hospital may met their need.

In 1972 child welfare statistics indicated that at least half of the New York City children ready for discharge from state hospitils on referral for placement to New York City's Burealu of C'hild Welfare were severely disturled adolescents. Many had het'n awating placement anywhere from 3 months to 3 years. There alsio were many emotionally disturbed adolescends from municipal and private psychiatric hospitals who were ready for discharge, and had been awaiting placement for prulonged periods.

The maijority of these disturbed adolescents were black and Puerto Rican, between 13 and 18 years old, from multiproblem ghetto families. They had histories of severe psychiatric disorders, long periods of institutionalization, acting-out be havior, suicidal and homicidal attempts, and drug use.

Linda R. Hoffman, M.S.W, ACSW, C.S.W. is Spccial Assistant to the Commissimer. Snecial Sertice's for Children. Nen lork Cily. Virginia Lehman. M.S.W., ACSW, C.S.W., is Social Work Supere isor of the Children and Adolescent Sertices. Bellevue Psychiatric Hospital, Nicw Yark. Eli D. Ze'c, M.S.W., ACSW, C.S.W., was Directur, Sfental Health Service's Department, Abbott House, Iritington, N.Y., at the time this paper teas uritten. He is mue Assistant Director, Hcsidential Program, V'isfa Del Mar, Child Care Serrices, Los Angeles. 
CHILD WELFARE / Volume LIV Number 4 April 197.5

Few child care ane ucies had prograns that enabled the'm to serve this populaterse. Spercial Services fer Children, the administrative arm of the Bureall "if Child Welfare, therefore embarked on an

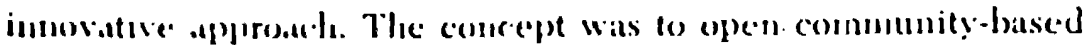
group lounes apeselled by at child care agency in affiliation with and located near pisychiatric hospitals with adolescernt services.

Sperdial Sorrices for Children would provide finding and administratise support. The child care agency nould provide the programming and expertise required for servicing the adoleseents in the group home. The hospitals would provide admission to the ir inpatient arvices if resuired and make a commitment to accerpt the children into the ir day treatment program. The day treatusent program would itsclurle a speeialized and individualized school pro-: grain, as well as psychotherapeutic, vocitional and recreational services.

\section{Prograın Goal}

The overall go:al was to help adulescents with long histories of institutionalization in elosed settings to adjust and function socially, educationally and vocationally in an open group home setting in the community.

Abbott House was the child care agency with which the group homes were to be developed. Bellevue Psichlittric Hospital, uhose Adole'scent Division's social work staff had submitted the original proposail for such a project, was selected as the: psychiatric backup for the first group home for eight adolescents. Long Island JewishHillside Psychiatric Hospital was selected as the psychiatric backup for the second gromp home for eight adolescents.

At the outset Special Services for Children and Ablyot House formally agreed with both Belleve and Hillside Hospitals as to the roles, responsibilities and services they would provide for their group hume projects. "This agreement permitted integration of their funding and resources to insure optimal delivery of service in the project.

Advisory committees for the Ablott House-Bellerue group home and for the Abbott House-Hillside group home, comprising representatives of the three facilities, were est.ablished. Jointly, the commitlee's were to:

1) select a progran director, to be on the Abbott House staff, directly responsible for programming and staffing the group home 
and coordinating group home services with those of participating houpitals:

2) select a hospital stalf psychiatrist responsible for providing theratpentic and comsultation services for the group homs";

3) monitor andel (evaluate the program;

4) estalhlish program policy;

5) make intake clecisions on the bissis of the program director's ancl the pengehiatrist, e. alluations:

6) discuss discharge platss.

Through the efforts of the two committees the projects were both phised in during the spring of 1973. Each group home accomnoditted oight adolescents. Girls were selecled as residents for both. homes, becanse statistices inclicated that the re was a greater muber of girls than hoys awaiting platement at that time.

\section{Program Model}

The programs have heen under evialuation during the ir operation. An attronpt his been made to develop a single nodel upon which to base future program planning for residential facilities to service emotionally disturbed adolescents. Through experience, it has been found that the most successful approaches are:

A. Development of a therapeutic milieu involving a synthesis of child care techniques with a psychiatric hospital's psychotherapeutic, educational, recreational, fumily planning and medical services.

B. Provision of an indiciclnalized program in relation to the youngsters' academic potentiol, current functioning and emotional stability, through the hospitil's special intramural school.

C. Location of the gromp home in close proxinity to the hospital. Such a location lielps insure attendance at the hospital's school. It is also strategic for emergency psychiatric and/or medical hospital care.

I). Location of the group home in a community supportive of the concept.

E. Development of intake policy as follows:

1) The child is referred by the public agency or the participating hospital. Each hospital home is allotted a percentage of the referrals bassed on its original written agreement.

2) The child is interviewed in the referring hospital setting by the program director and hospital psychiatrist.

3) A cletermination is made that the child has the potential to 
CHILD WELFARE , Volume LIV Numter 4 April 1975

establish one-lo-inse and/or group relatlomship and is motivalted (1) attertipt to function in an ope'n group home setting.

4) A one-ding visit is made by the chilel to the gromp home and the hospital', school.

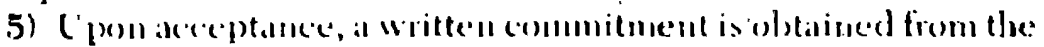

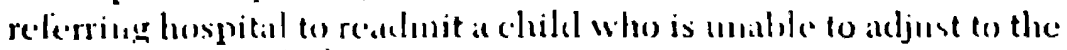
gromp home within 9') days.

6) The chuld is placed directly from the referring hospital into thi. groul) liome.

F. Develepment of discharge policy as follows:

1) Discharge platus are discessed with the advisony committece.

2) Fin.t dischiorge de cisions for the group home are mate hy the. prostan director. Followup planuing for children is the responsibility of the child care algences.

3) Final dischange decisions for the day hospital progran atre made be the day hospital staff.

6. Provision of individual and grenu theratp! b! perchiatrists and professional social workers. These therapists, alung with child care stitf, mals also conducl life-space interviews.

H. Provision of three shifts of child carce stalf within each 24-hour periend, ruther than lise-in pitrental persons. This stalfing paltern relieves the stress of working with sich al ses erels disturbed populattion, unable tocone with the more intense pirent-child relationship.

1. Promotion of awareness, understanding ind involvement in the residents totil actirities througl combined meetings of the group) lome and hospital stalfs.

J. Enhancentent of positive feelings and relationships loward peers and community through emphasis on commmnity activities such als joint shopping trips, movies, ice skatting, course's at the "Y," coluntecer.work, cetc.

\section{Method of Program Evaluation}

Evalnation of the gremp lome programs has been based on whe ther the? have andieved therir overall goal of secial, educational and verational adjustment. Social adjustme-nt has becen measured on the hasis of the younesters' ability to rematin and finction in open commmnit!-bincel grompl homo settings.

The criterial for colucational adjustunent have been school attendance and andievement. Academic achievement has been evaluated 
by comparing corrent mathematies and reading scores with those oistaine d upout adenission.

At this time it is not possible to evaluale vocational adjustment definitely, as there is only one chilel whe respuires vocotional training. She is din telerral to a rocitional tritining prongran.

\section{Social Adjustment}

During the first sear of operation of the two group lomes (1973. 197-t) there were 29 athissions. Sixte.'n girl are currently in residence: exight from 9 months to a yeatr, three from 6 to 9 monthis, alnd five up to 6 months from their admission dates.

The 1:3 children who did not rematin were dischanged during the first fo months of the programs: existence. The majority of the youngsters left within a month of their admissmon dates. There hate been mo discluarges during the last 6 months. The dropouts ceased simmltancously with the solidilication of the tri-panty relationships through the Advisory Committee, resolution of inajor administrative problems, development of a more relewant intake policy and more cohesive inter- and intra- staff-resident relationships in the group homes.

It is not posisible to determine the degree of be havior modification that has occurred or its permanence, due to the relatis ely brich time in treatment in a community setting. Although positive and negative fluctuations have occurred in the youngsters behavior over the last year, there has been no adverse community reaction to their presence. In general, the luehavior of the resiclents has at least remained the same in the open group home setting as it wals in a closed setting. In some cases there are indications of significant improyement. The acting-out, aggressive tendencies of at least six of the girls have: noticeably subsided.

\section{Educational Adjustment}

The hospitals' special schools have been providing a structured social experience along with an inclividualized educational approach for these youngsters, most of whom have histories of poor school attendance, adjustnent and achievement. All but one of the 16 girls in residence have been attending school regularly. Twelie are attending the hospitals' special schools, one is attending a community high school and two are attending college. Two of those . attending hospital school are currently candidates for high school. 
equivalency examinations. The one child not attending school the girl on reterral to a socational truining program) is receiving remedial help) at the group home.

The: potential for acatemic achiesement among these youmgsters varies. Their IQs rimge from mildly retarded to al owe-alveragge. Academic progress has been meatured in lerms of :me improvement in reacling and math scores firom the date of admission to the present. Ten of the 15 residents who attend school have shown progress in readiug and math score's, with chear inclications that the re is a correlation between the ehild's length of stay and her edacational progress.

\section{Conclusion}

The programs have demonstrated that there are severely disturbed adolescents who are able to function and progress socially and educationally in these ope'n commmnity-batsed group home settines.

A major factor in the program's success is that optimal federal, state and local funding has been obtained for operational expenses. Another factor is that the participating agencies irew up agreenents defining the services and responsibilities of eatch.

'I he most positive ongoing (omponent in the programs' development has been the ardisory committe of represcentatives of the three participatting agencices. Though the agencies' interests and service mandates mat have differed, the committee has been the velicle for fostering the trust and understanding that enabled its me-mbers to develop the common gual of providing quality administration and services in the group homes. The support of the community also licelped strengthen the group homes. As mentioned earlier, notwithstanding fluctuations in the alolescents' actingout hehavior there lias been no adverse community reaction.

Finally, the therapeutic, educational and recreational program developed to maintain the roungsters' interest and im olvement and the positive staff-resident relationships have provided the mitien esserutial for successs.

Further resejarch on this type of program is needed. It should include a determination of which severely disturbed aclolescents can bencefit from this kind of setting, which reguire a more structured settiıg. and " hat treatment modalities have the most positive longrange effects. Nevertheless, in view of the programs' current success, local child care agencies and psichiatric hospilails have begun 
to show interest in developing their own services based on this model or modifications of it.

Special Sersices for Children recently opented another group heme with Ahhott House and Bedlevere Psychiatric Hospital. This home is for eight eneotional disturberl adolencent boys. Special Services for Children plaus to open soon at least two more group homes foremotimbally disturbed adole'secents, using the tri-party approach or variation of this merelel. 